\title{
Yükselen Ekonomilerde Enerji Etkinliğini Talep Yanlı Etkileyen Faktörler
}

\author{
Mustafa NAIMOĞLU (https://orcid.org/0000-0001-9684-159X), Department of Economics, Bingöl University, \\ Turkey; e-mail: mnaimoglu@bingol.edu.tr
}

Mustafa AKAL (https://orcid.org/0000-0002-0504-100X), Department of Economics, Sakarya University, Turkey; e-mail: akal@sakarya.edu.tr

\section{Demand Sided Factors Influencing Energy Efficiency in Emerging Economies}

\begin{abstract}
Emerging Economies' most important energy source is either renewable energy or efficient and effective energy use. In this study, demand-side factors that explain energy efficiency in 23 Emerging Economies were investigated between 1990 and 2018. Common Correlated Effects Mean Group (CCEMG) and Extended Mean Group (AMG) panel estimators were used for model estimation. Findings indicate that industrial production, services, foreign direct investment, fixed capital investment, foreign openness ratio, increases in exports and imports have a positive effect on energy efficiency. In contrast, population, carbon dioxide emission, and increases in oil and coal prices negatively affect energy efficiency. It has been found that competitive production and a rise in foreign trade increases energy efficiency in Emerging Economies.
\end{abstract}

Keywords : Emerging Economies, Energy Efficiency, Demand-side Models.

JEL Classification Codes : F6, Q4, C33.

\section{Öz}

Yükselen Ekonomiler için en önemli enerji kaynağı ya yenilenebilir enerji ya da enerjinin tasarruflu, verimli ve etkin kullanılmasıdır. Bu çalışma da 23 Yükselen Ekonomi için 1990-2018 döneminde enerji etkinliğini açıklayıcı talep yanlı faktörler araştırılmıştır. Model tahmini için Ortak İlişkili Etkiler Ortalama Grup (CCEMG) ile Genişletilmiş Ortalama Grup (AMG) panel tahmincileri kullanılmıştır. Bulgular genel olarak endüstriyel ve hizmetler üretimi, ithalat, doğrudan yabanc1 sermaye yatırımı, sabit sermaye yatırımı, dış açıklık oranı, ihracat ve ithalat artışları enerji etkinliğini olumlu etkilerken nüfus, karbondioksit emisyonu, petrol ve kömür fiyat artışları ise olumsuz etkilemektedir. Yükselen Ekonomiler 'de rekabetçi üretim ve dış ticaret artışlarının enerji etkinliğini artırdığı bulunmuştur.

Anahtar Sözcükler $\quad$ : Yükselen Ekonomiler, Enerji Etkinliği, Talep Yanlı Modeller. 


\section{Giriş}

Ülkelerin dünya üzerinde profil göstergeleri genel olarak makroekonomik göstergelerdir. Bunların başında büyüme rakamları gelmektedir. Yükselen Ekonomiler yüksek büyüme rakamlarıyla küresel ekonomik büyümenin lokomotifi sayılırlar. Enerji ise bu büyümenin önemli bir girdisidir. Yükselen Ekonomiler'in bu girdiyi çoğunlukla fosil yakıtlardan karşılaması ve fosil yakıtların ömrünün giderek azalması, enerji fiyatlarında yaşanan artış, çevreye verilen zarar, artan nüfus ve yaşanan rekabet enerji verimliliğine yönelik bilimsel çalışmalara olan ihtiyacın şiddetini artırmıştır. Dolayısıyla değişen pazara ve talebe hızlı bir şekilde cevap verebilmenin yanında; çevreye verilen zararın azaltılması için geçmiş politikaları, dünyadaki enerji değişim ve gelişimleri ve bunları etkileyen faktörleri analiz etmek gerekecektir.

Diğer taraftan Yükselen Ekonomiler için enerji fiyatlarında yaşanan artış, enerji konusunda dışa bağımlılık, enerji maliyetlerinin ekonomileri içindeki yüksek payları ile ortaya çıkan cari açıklar, aşırı ve bilinçsiz enerji tüketimi gibi nedenlerle birlikte enerji verimliliği veya etkinliği artırımı konusu güncelliğini korumaktadır. Bu durum enerji verimliliğini açıklamada talep yanlı faktörlerin de dikkate alınması gerektiğini işaret etmektedir. Bu doğrultuda literatürde yapılan çalışmalar ile birlikte talep yanlı değişkenlerin dikkate alındığı talep tahmin modelleri ile enerji etkinliği açıklanmalıdır.

Enerji etkinliğini belirleyen talep yanlı bazı faktörler bilinmektedir. Fakat hangi faktörün, hangi ülkede, hangi sektörde, hangi dönemde enerji etkinliğini nasıl ve ne yönde etkilediğini belirlemek oldukça zor olmaktadır. Ancak ilgili faktörlerin enerji etkinliği üzerinde ortalama eğilimlerini ekonometrik modellemelerle ölçmek mümkündür. Enerji etkinliğini talep yanlı belirleyen fiyat değişkeni incelendiğinde; enerji fiyatlarında özellikle de fosil yakıtlarda yaşanan artış kaynağ 1 fosil yakıt olan enerji üretim maliyetlerini artırdığı için ikame derecesine göre çevre dostu enerji kaynak kullanımına doğru kaydırmaktadır. Bu ikamenin her ülke için kolay olmaması, ülkelerin coğrafi konumu, geliri, yetersiz teknolojik alt yapısı gibi nedenlerden dolayı hala birçok ülke için fosil yakıt kullanımının uzun yıllar süreceği öngörülmektedir. Ayrıca fosil yakıt kaynakları Yükselen Ekonomiler'de yetersizdir. Bu yüzden fosil yakıt kullanımının artışı gelişmekte olan ekonomiler için dış ticaret açığının ana nedeni olmaya devam etmesi kaçınılmazdır (Zeren \& Akkuş, 2020). Ayrıca fosil yakıt kullanımının artması çevresel bozulmaya ve sera gazlarının ana kaynağı olan karbondioksit $\left(\mathrm{CO}_{2}\right)$ emisyonunun artmasına da sebep olmaktadır. Çünkü $\mathrm{CO}_{2}$ emisyonlarının büyük çoğunluğu fosil yakıt (kömür, petrol ve doğalgaz) kaynaklarının tüketiminden kaynaklanmaktadır. Ayrıca bu ülkelerde enerji tasarrufu ve enerji tüketimini azaltma politikalarının yokluğu veya yetersizliği çevre kirliliği üzerinde baskı kuran emisyonun artışına neden olacaktır (Hossain, 2011).

Enerji etkinliğini etkileyen talep yanlı faktörlerden gelirin artması daha fazla harcama yapılması, teknolojik gelişmeleri hızlandırması, enerji kaynak çeşitliliğini artırmasından dolayı önemlidir. Elde edilen gelir (yurtiçi üretim) ise enerjinin kullanımı ile ortaya çıktığı için enerjinin etkin kullanılması gelir üzerinde önemli bir belirleyici rol oynayacaktır. 
Enerji etkinliğini etkileyen talep yanlı faktörler arasında Yükselen Ekonomiler için DYY (Doğrudan Yabancı Yatırım)'lar da önemli bir yere sahiptir. Çünkü bu ülkeler yüksek büyüme rakamları için yeterli düzeyde sermaye birikimine sahip olmayabilirler. DYY ev sahibi ülkeye hem sermeye getirecek hem de teknoloji transferi sağlayacaktır. Bu durum ülkenin makroekonomik göstergelerine olumlu yansıyacaktır (Syzdykova, 2019). Ayrıca bu ülkeler için en önemli enerji kaynağı enerjinin tasarruflu, verimli ve etkin kullanılmasıdır. $\mathrm{Bu}$ kaynağı sağlayacak en önemli itici güç ise yatırımlardır. Çünkü yatırımlar teknolojik ilerlemenin bir sürücüsüdür. Teknolojik ilerleme teknik verimliliği artırarak aynı veya daha fazla çıktıyı daha az enerjiyle elde edilmesine olanak sağlayacaktır (Chang vd., 2018).

Yükselen Ekonomiler için nüfus artışının da enerji etkinliği üzerinde etkisi büyüktür. Nüfus, enerji talebini yönlendirmede ve enerji güvenliği konusunda ciddi sonuçlar doğurmaktadır. Gelişmekte olan ülkeler için nüfusta yaşanan \%1'lik bir artış uzun vadede enerji talebini \%4,16 oranında artırmaktadır (Nepal \& Paija, 2019). Bu durum dünya nüfusunun \%82'sine sahip Gelişmekte olan ülkeler için enerji etkinliği konusunda nüfusun ne kadar çok önemli olduğunu göstermektedir (Güney, 2017: 1259).

Yükselen Ekonomiler'de enerji etkinliği için İhracatın da önemi büyüktür. Çünkü Yükselen Ekonomiler ihracatı genellikle ithal ettiği malları işleyerek sağlamaktadırlar. Ve ihracat artışı ülke ekonomilerinin makroekonomik göstergelerine olumlu yansımaktadır. İhracat artışları ekonomilerin gelir düzeyini arttırabilecek, daha sonra ihracatta yoğunlaşmaya ve bu yoğunlaşma aşamasında enerji etkinliğini artırabilecek ürünler üretmeye odaklanabilecek ve bu şekilde enerji talebini azaltacaktır (Raza \& Shah, 2019).

Bu çalışmada IMF tarafından yükselen ekonomi olarak adlandırılan 23 ekonomi için enerji etkinliğinin talep yanlı belirleyicileri ortaya konulmaya çalışılmıştır. Söz konusu ülke grubunun seçiminde önemli görülen temel belirleyiciler; yüksek büyüme rakamları, yüksek ve giderek artan nüfus, dünya ticaretinden alınan pay artışı, artan enerji ithalatı, enerji kaynakları arasında fosil enerji kullanımının yüksek paya sahip olmasından dolayı artan fosil yakıt kullanımı, yeterli düzeyde olmayan teknoloji, yaşanan yüksek enerji kayıpları ve artan $\mathrm{CO}_{2}$ salınımıdır. Ayrıca bu ekonomilerin enerji alanında çoğunlukla dışa bağımlı olmasının artan enerji talebiyle ve enerjinin etkin/verimli kullanılma potansiyellerinin tam olarak gerçekleşmemesiyle doğru orantılı olmasından dolayı enerji talebini yani dışa bağımlılığ azaltmanın altındaki faktörleri belirlemek bu ekonomiler için önemli olduğundan bu çalışma bu ülke ve diğer ülke yöneticileri için yol gösterici olacaktır.

Literatürde enerji yoğunluğunu (tersine enerji verimliliğini) etkileyen faktörlerin birçok çalışmada arz ve talep ayrımı yapmadan birkaç değişkenle araştırıldığı görülmektedir. Ancak bu çalışmada enerji etkinliğini/verimliliğini talep yanlı etkileyebilecek birçok değişkenin yer aldığı bir çalışmadır. Bunu yaparken enerji etkinliğini etkileyen talep yanlı faktörler arasında enerji fiyatları, gelir, demografik ve diğer iktisadi birçok değişken kullanılmıştır. Yine çalışmada talep yanlı faktörlerle enerjinin etkin kullanımını belirleyen etmenler güncel dönem verileri ile araştırılmıştır. 
Çalışmanın ilk bölümünde literatür taraması ele alınmış, sonra değişkenler ve kullanılacak yöntem belirtilerek analiz ve bulgulara yer verilmiş ve yorumlar getirilmiştir.

\section{Literatür}

Yükselen Ekonomiler'de enerji etkinliğini derinlemesine araştırabilmek için ilk olarak literatürden değişkenlerin belirlenmesi gerekecektir. İktisat teorisine göre talebi etkileyen faktörlere bakıldığında en önemlileri gelir ve fiyat olarak karşımıza çıkmaktadır. Sonraki faktörleri makroekonomik değişkenler, demografik yapı, iktisadi, kurumsal ve yapısal faktörler olarak sayabiliriz. Bu faktörlerin doğru analizleri ve doğru politikaları Yükselen Ekonomiler özelinde tüm dünya için enerji talebini azaltıcı yönde bir etki yapacaktır. $\mathrm{Bu}$ ise hedeflenen enerji etkinliği artırımına olumlu yansıyacaktır. Çünkü Yükselen Ekonomiler için en önemli enerji kaynağı ya yenilenebilir enerjidir ya da enerjinin tasarruflu, verimli ve etkin kullanılmasıdır. Yenilenebilir enerji kaynakları bu ülkelerin enerji kaynakları içerisindeki paylarında artış göstermektedir ancak hala en yüksek payları ithal ettikleri fosil yakıtlarla karşılamaktadırlar. Bu yüzden bu ülkeler için en önemli enerji kaynakları enerjinin tasarruflu, verimli ve etkin kullanılması olacaktır.

Yükselen Ekonomiler'de GSYİH'yı oluşturan sektörel üretimin enerji etkinliği üzerindeki etkilerini ayrıntılı görebilmek için sektör gelirlerinin modellere dâhil edilmesi önemlidir.

Gelir (Üretim): İktisat teorisine göre gelir, mal talebinin önemli bir belirleyicisidir. Ekonomilerde enerji kullanımının ve bu kullanımından dolayı çıktının büyük kısmı sanayi, hizmetler ve tarım sektörleri tarafından oluşturulmaktadır. Ekonomilerin gelirinin ve/veya üretiminin artması beraberinde teknolojik gelişmeleri getirmektedir. Bu durumda üretim veya gelir enerji etkinliliğinin birincil belirleyicisidir. Akal (2016) kişi başı üretim artışının enerji etkinliğini artırdığını bulmuştur. Hatzigeorgiou vd. (2011) gelirden enerjinin etkin kullanımına doğru tek yanlı nedensellik olduğunu bulmuştur. Zhang vd. (2011) Tobit regresyonunu kullanarak toplam faktör enerji verimliliği ile kişi başına gelir arasında U şekline sahip bir ilişki olduğunu elde etmiştir. Chen vd. (2019) ise çalışmasında gelirin 1 birim marjinal artışının, enerjinin etkin kullanımında \%0,735 - \%0,852'lik bir iyileşmeye katkıda bulunacağını elde etmiştir. Bu bölümde toplam gelir yerine toplam gelirin yapısı ve sektörel olarak enerji etkinliği üzerindeki etkilerini daha ayrıntılı görebilmek için toplam gelir içerisindeki paylarına göre sektörel gelirler kullanılması tercih edilmiştir.

Enerji Fiyatları: İktisat teorisine göre fiyat mal talebinin önemli bir belirleyicidir. Gamtessa \& Olani (2018) Kanada'nın sanayi genelinde; enerji fiyatında yaşanan pozitif bir şokun enerji-sermaye ve enerji-çıkış oranlarını azalttığını göstermiştir. Ayrıca enerji fiyat artışlarının, enerji kaynakları arasında ikame yoluyla ve esas olarak sektör düzeyinde saf verimlilik kazanımları yoluyla uzun vadede endüstriyel enerji yoğunluğunda bir azalmaya neden olacaktır (Lescaroux, 2008: 1069). Hang \& Tu (2007) Çin için enerji fiyatlarının enerji yoğunluğu üzerindeki etkilerini araştırmıştır. Bulgular enerjinin etkin kullanımını artırmak için enerji fiyatlarının artırılmasının etkili bir politika olduğu yönündedir. Ayrıca 
yenilenebilir enerji bir ekonominin enerji etkinliğini artırması için önemli bir faktördür. Çünkü bu enerjiler başlangıç maliyetleri dışında bir maliyeti bulunmayan ve çevre dostu enerjilerdir. Ayrıca enerji konusunda dışa bağımlı ülkeler için bu bağımlılığı azaltacak önemli bir araçtır. Bu yüzden yenilenebilir enerji kullanımının benimsenmesi fosil enerji kaynaklarının ikamesi için önemli bir alternatiftir (Chang vd., 2009). Enerji fiyatlarındaki artış, fosil yakıtlara olan bağımlılığı azaltma isteği ve daha temiz bir çevre için dünya artık daha temiz enerji kaynaklarına yönelmektedir. Bird vd. (2005)'ne göre doğalgaz fiyatlarında yaşanan artışlar kaynağı doğalgaz olan jeneratörlerin elektrik üretim maliyetlerini artırdığ için rüzgâr enerjisinin kullanımını artırmıştır. Marques vd. (2010) petrol, doğalgaz, kömür ve nükleer enerji kaynakları fiyatlarının yüksek olması ikame derecesine göre yenilenebilir enerji kullanımını artırdığını belirtmiştir. Benzer şekilde Menz \& Vachon (2006)'e göre fosil yakıtlarda meydana gelen fiyat artışları tüketiciler açısından çevre dostu alternatif enerjiler için daha cazip hale gelecektir. Sadorsky (2009)'e göre petrol fiyatlarında yaşanan artışlar yenilenebilir enerji kullanımı üzerinde az da olsa olumsuz bir etkiye sahiptir. Benzer şekilde yüksek doğalgaz ve petrol fiyatları artışının kömür kullanımının önemli bir itici gücü olduğunu vurgulamaktadır. Ayrıca yüksek petrol ve doğalgaz fiyatları beraberinde i) bu enerji kullanımlarındaki azalmanın yanında küçük büyüme rakamlarını getireceği, ii) enerjinin nasıl daha etkin kullanılabileceğini ve iii) alternatif enerji kaynakları arayışını ve ikame edilmesini sağlayacaktır (Van Ruijven \& Van Vuuren, 2009). Antonietti \& Fontini (2019) ise çalışmalarında 120 ülke için enerji fiyatlarının enerji etkinliği üzerindeki etkisini araştırmıştır. Çalışma bulguları petrol fiyatını artırmayı amaçlayan küresel bir politikanın enerji etkinliğinde sınırlı bir artışa neden olacağını, ancak bu artışın dünyadaki bölgeler arasında önemli ölçüde farklılık göstereceği yönündedir.

Doğrudan Yabancı Yatırımlar: Doğrudan Yabancı Yatırımlar (DYY), yabancı yatırımcıların kâr amaçlı olarak yanlarında getirdikleri kaynaklarla bir ülkede yeni bir şirket veya var olan bir şirkete ortak olmak şeklinde yapılan yatırımlardır (Uygur, 2012: 87). Bu yatırımlar kâr amaçlı olduğu için yatırımın yapıldığı ülkeye sermaye ve teknoloji transferi sağlayacaktır. Bu teknoloji transferi yayılım etkisiyle diğer sektörlere dağılım gösterecek ve üretim yapılırken ihtiyaç duyulan enerji talebini azaltıcı yönde bir etki yapacaktır.

1990’dan itibaren küresel pazarın sınırları genişledikçe ülkeler arasında sermaye dolaşımı ilerlemiştir. Küresel ticaret ve DYY eşi benzeri görülmemiş yüksekliklerde gelişmiştir. Fan (2002)'a göre DYY aracılığıyla ev sahibi ülkelere gelen teknolojinin işletmeler üzerinde yayılım etkisi yaparak hem ev sahibi ülkenin sermaye ihtiyaçlarını karşılayabilecek hem de teknolojinin yayılım etkisiyle enerji etkinliğine yol açabilecektir.

Pan vd. (2019) DYY miktarının Çin’deki enerji etkinliği üzerindeki etkisini ampirik olarak incelemiştir. Bulgular yüksek miktarda DYY, enerji dağıtım teknolojisi sayesinde Çin işletmelerinin enerji tasarrufu teknolojisi düzeyini ve enerji tasarrufu yönetimi yeteneğini etkin bir şekilde artırabildiği yönündedir. Wang (2017)'nin Çin için 2001-2013 yılları arasında DYY ile enerjinin etkin kullanılması arasındaki ilişkiyi dinamik panel modeliyle araştırmış ve DYY'ın enerji etkinliğini önemli ölçüde arttırdığı sonucuna ulaşmışlardır. Çünkü DYY sermaye, teknoloji ve bunların yönetimden meydana gelmiş paket bir kaynaktır 
ve enerji etkinliğini artıcı yönde yayılım etkisine sahiptir. Mingyong vd. (2006) Çin için teknoloji yayılımları, emme kapasitesi ve ekonomik büyüme üzerine araştırma yapmışlardır. Bulgular Çin için DYY'ların teknolojinin yayılmasına ithalattan daha fazla yayılma kanalı olduğunu göstermiştir. Adom (2015) Güney Afrika'da enerji yoğunluğunun belirleyicilerini araştırırken DYY'ın sanayi de teknolojik aktarımı artırdığı, bunun da enerji etkinliğine neden olduğunu bulmuştur. Çünkü teknoloji ve teknik ilerleme teknik verimliliği, teknik verimlilik ise enerji etkinliğinin gelişmesinde büyük etkiye sahiptir.

$\mathrm{CO}_{2}$ Emisyonu: Son zamanlarda iklim değişikliği, çevresel bozulmalar ve küresel ısınma tüm dünyanın karşı karşıya kaldığı önemli bir sorun olmuştur. Bu sorunlara neden olan gazların başında sera gazları gelmekte ve tüm dünya bunların azaltılması için çeşitli politikalar geliştirmekte ve uygulamaktadır. Sera gazları metan, su buharı, karbondioksit ve nitroksit gazlarından oluşmaktadır. Bu gazlar arasında sera gazını artıranların başında karbondioksit $\left(\mathrm{CO}_{2}\right)$ gelmektedir. $\mathrm{CO}_{2}$ salınımının nedeni ise kömür, petrol ve doğal gaz gibi fosil yakıtların kullanımıdır (Aslan, 2009: 1429). Tian vd. (2016) çalışmalarında Çin'de karayolu taşımacılığında ticari kamyonlarda enerji etkinliği ile $\mathrm{CO}_{2}$ emisyonu arasındaki ilişkiyi araştırmışlardır. Çin hızlı ekonomik büyüme ve karayolu taşımacılığının gelişmesiyle en fazla petrol kullanan ülkelerden biri haline gelmiştir. Bulgular enerji etkinliği yüksek olan ticari kamyonların düşük emisyonlara sahip olduğunu göstermiştir. Vieira vd. (2018) Brezilya için enerjinin etkin kullanılması programları tarafından $\mathrm{CO}_{2}$ emisyonlarının değerlendirmesini yapmışlardır. Bulgular sera gazı emisyonlarının azaltılmasında en etkili araçlardan birinin enerjinin etkin kullanılması olduğu bulunmuştur. $\mathrm{Bu}$ etkinlik ise teknolojik verimliliği yüksek olan aydınlatma ve soğutmanın bulunduğu konut sektöründe yaşanmıştır. Chong vd. (2019) Malezya için $\mathrm{CO}_{2}$ emisyonlarını belirleyen başlıca faktörleri belirlerken elektrik tüketimindeki artışların $\mathrm{CO}_{2}$ emisyonlarını önemli ölçüde artırdığını elde etmiştir. Gu vd. (2019) Çin için enerji teknolojik ilerleme, enerji tüketimi ve $\mathrm{CO}_{2}$ emisyonları arasındaki ilişkiyi araştırmıştır. Enerji tüketimi ve enerji teknik ilerlemenin $\mathrm{CO}_{2}$ emisyonlarını artırdığı ancak zamanla azaldığı ve bu emisyonlardaki azalışın veya artışın enerji konusunda teknolojik ilerlemeye bağlı olduğunu belirtmişlerdir. Neves vd. (2017) 15 OECD ülkesi için ulaştırma sektöründeki enerji tüketiminin $\mathrm{CO}_{2}$ emisyonlarını nasıl etkilediğini araştırırken elektrik kullanımının fosil yakıt kullanımını azalttığı ve $\mathrm{CO}_{2}$ emisyonlarını artırdığ 1 sonucunu elde etmiştir (Valadkhani vd., 2019).

Yatırım: Enerji kullanmak dünya ekonomileri için çok önemlidir. Teknoloji içeren sermaye yatırımları enerji tasarruf edici yatırımlar şeklinde geliştiğinden enerji verimini/etkinliğini artırmada önemli role sahiptir. Yatırımlar arttıkça enerjinin önemi artmakta ve enerjiye yapılması gereken yatırımı da beraberinde getirmektedir. Diğer taraftan enerjinin kullanılabilmesi için bazı dönüşümlere ihtiyaç vardır ve bu durum yüksek teknolojili yatırımlarla mümkündür. Ülkeler bu şekildeki yatırımları hem enerjinin üretimi hem de enerjinin etkin kullanımını sağlamak için yapmalıdırlar (Mucuk \& Uysal, 2009). Benzer şekilde Kejun (2009)'a göre enerjinin etkin kullanımı ve tasarruf iyileştirmeleri için teknolojik ilerleme önemlidir. Enerjinin yoğun olarak kullanıldığı sektörlerde yaşanan yüksek enerji verimli teknolojiler eski teknolojilerden hem daha ucuz hem de daha güçlü pazar rekabeti nedeniyle hızlı bir şekilde yayılmaktadır. Ulusoy (2006) ise Türkiye için 
enerji kullanımının ekonomik büyüme üzerindeki etkisini araştırırken ülkelerin büyüme için enerjiye ve enerji konusunda yatırım yapmaya ihtiyacı olduğunu belirtmiştir.

Diğer taraftan Chang vd. (2018) çalışmasında OECD ülkeleri için yüksek devlet verimliliğinin enerjinin etkin kullanılması üzerindeki etkisini araştırmıştır. Brüt sermaye oluşumunu, yatırımla gösterilen GSYİH'nın yüzdesini teknolojik ilerlemenin belirli bir sürücüsü olarak kullanmıştır. Pratik olarak ekonomik teoriye göre yatırım eski tesislerin yeni tesislerle değiştirilmesine olanak sağlayacak ve daha verimli teknolojiler sunacaktır. Teknolojik ilerleme, enerjinin korunmasını ve enerjinin etkin kullanımının iyileştirilmesini kuvvetle destekleyecektir. Dolayısıyla brüt sermaye oluşumu enerji etkinliğinin artmasına neden olacaktır. Ayrıca enerji kullanımına bağlı teknoloji açığının enerjinin etkin kullanılması üzerine önemli bir negatif etkisi olduğu sonucuna ulaşmıştır.

Dış Ticaret: İhracat ve ithalatın enerji etkinliği üzerine önemli bir etkisi olduğu kaçınılmazdır. Dış alım ve satım Yükselen Ekonomiler'in büyümesinde ekonomik büyümeyi güdüleyen dinamik faktörlerdir. Zhao \& Lin (2019) çalışmalarında Çin tekstil endüstrisinde dış ticaretin, enerjinin etkin kullanımı üzerindeki etkisini araştırmıştır. Çalışma sonuçları dış ticaret ile tekstil endüstrisindeki enerji etkinliği arasında olumlu bir geri dönüş olduğunu göstermektedir. Bununla birlikte ithalat, enerji etkinliğini ihracattan daha fazla etkilemektedir. Tekstil endüstrisindeki dış ticaret, enerji etkinliği üzerinde farklı etkileri olan ithalat ve ihracat ticaretine ayrıldığı sonucuna ulaşmışlardır. Boqiang \& Hongxun (2015) ise dış ticaretin hem teknolojik ilerlemenin önemli bir kaynağ 1 hem de enerji etkinliğinde önemli bir belirleyici faktör olduğunu ortaya koymuştur. Enerji etkinliğini artırmak enerjiyi korurken ve emisyonları azaltırken ekonomik büyümeyi sağlamak için önemli bir araçtır. Dawei vd. (2010) AR-GE teknolojisi yayılmalarının Çin'de toplam faktör verimliliği üzerindeki etkisini araştırmıştır. Bulgulara göre dış ticaret teknolojik ilerlemeyi, bu ilerleme de tekstil endüstrisinin enerji etkinliğini artırmada önemli olduğunu göstermiştir.

Dış Ticaret Açıklık Oranı: Hull vd. (2009) Avrupa genelinde İrlanda özelinde enerji etkinliği düzenleyici yükümlülüklerine yanıt olarak geliştirdiği modelde teknolojik gelişmenin enerji etkinliğine yol açabileceğini, etkinliğe yapılan yatırımların endüstriyel rekabet gücünü artırabileceğini belirtmiştir. Bu nedenle ticaret açıklığı ülkelerin teknolojik yeniliklerle verimli üretim tekniklerini geliştirerek enerji etkinliği konusunda daha fazla firsatlar sunabilir.

Diğer taraftan, Grossman \& Krueger (1991) Kuzey Amerika'da serbest ticaret anlaşmasının çevresel etkilerini araştırırken ülkeler arasında yüksek uluslararası ticaretin enerji talebini genişleterek toplam üretimde bir artış meydana getireceğini göstermiştir. Çünkü daha büyük uluslararası ticaret daha yüksek üretimi ve bu durum daha yüksek enerji tüketimini gerçekleştirecektir. Bu durum daha düşük enerji etkinliği ile sonuçlanacaktır (Chang vd., 2015: 1184). Yani aşırı üretim enerji israfına neden olacaktır. Örneğin Akal (2015) Çin, ABD, AB ve Japonya arasında, Çin'in aşırı üretim artışının hem kendi hem de AB'nin enerji kullanımında etkinsizliğe yol açan bir yapı olduğunu bulmuştur. 
Dış Ticaret Açıklık Oranının enerji etkinliği üzerine etkisi, Dış Ticaret Açıklık Oranının teknolojik verimliliğinden doğan kazançlar ile aşırı üretimin getirdiği enerji israfının olumsuz etkisinden herhangi birinin üstünlüğüne göre şekillenecektir.

Literatür araştırması neticesinde enerjinin etkin kullanımını etkileyen faktörler; enerji talebini en önemli belirleyicileri arasında bulunan gelir ve fiyat, teknoloji ve sermayenin aktarıldığı DYY, artan fosil yakıt kullanımından dolayı ortaya çıkan $\mathrm{CO}_{2}$ emisyonu, teknoloji içeren sermaye ve enerji tasarruf edici yatırımlar, büyümeyi etkileyen ihracat ve ithalat, ekonomilerin teknolojik yeniliklerle verimli üretim tekniklerini geliştiren diş ticaret açıklığı ve nüfus artışıdır. Tüm bu etmenler enerji etkinliğini doğrudan veya dolaylı olarak etkileyebilir.

\section{Ekonometrik Yöntem ve Bulgular}

$\mathrm{Bu}$ kısımda enerji etkinliği ile enerji etkinliğini etkileyen talep yanlı faktörler arasındaki uzun dönem ilişkinin varlığı incelenecektir. İlk olarak değişkenlere birimler arası korelasyon testi yapılarak birim kök test araştırması yapılmıştır. Sonra bütün değişkenlerin birinci farkta durağan olması eşbütünleşme ilişkisi bulunabileceğini düşündürerek modellerde yatay kesit bağımlılı̆̆ı ve eğim parametrelerinin homojenliği araştırılmıştır. Daha sonra Durbin-Hausman testi yapılarak eşbütünleşme ilişkisi test edilmiş ve uzun dönem katsayıları için CCEMG ve AMG tahmincileri kullanılmıştır.

Değişken sayısının fazla olması, çoklu doğrusal bağlantı problemini bertaraf etmek için korelasyon ve VIF değerleri hesaplanmış ve her bir değişkenin etkisini tahmin etmek için de toplamda 9 model oluşturulmuştur. Öncelikle korelasyon katsayıları ve VIF değerleri dikkate alınmadan tüm değişkenlerin yer aldığı Model1 ve sadece enerji fiyatları ve sektörel gelirlerin yer aldığı Model2 oluşturulmuştur. Diğer 7 model ise VIF değerleri 10'u geçmeyecek şekilde oluşturulan modellerdir.

\subsection{Değişkenlerin Tanıtımı}

Çalışmadaki bağımlı değişken olan enerji etkinliği (LEE), birim enerji başına üretilen maksimum çıktının logaritmasıdır. Yani LEE=Log [GDP (2010 US\$ sabit fiyatlarıyla) / Toplam enerji kullanımı (ktoe)] olarak alınmıştır. Grafik 1, 1990-2018 arasında çalışmada kullanılan Yükselen Ekonomiler'in enerji etkinliği eğilimini göstermektedir ${ }^{1}$. Bu ülkelerin enerji etkinlik grafiklerinin hassas ve büyük dalgalanmalara sahip olması enerji etkinliğini etkileyebilecek faktörlere karşı ne kadar çok duyarlı olduğunu göstermektedir.

1 IMF'nin 2015 yllında yayınlanan dünya ekonomik raporunda Arjantin, Bangladeş, Brezilya, Bulgaristan, Şili, Çin, Kolombiya, Macaristan, Hindistan, Endonezya, Malezya, Meksika, Pakistan, Peru, Filipinler, Polonya, Romanya, Rusya, Güney Afrika, Tayland, Türkiye, Ukrayna ve Venezüella şeklindeki 23 ülke Yükselen Ekonomi olarak sinıflandirılmıştır (IMF; WEO, 2015: 124). 


\section{Grafik: 1}

\section{Bireysel Enerji Etkinlik Grafikleri 1990-2018 (GSYIH/Ktoe)}

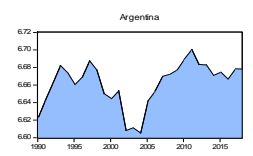

China

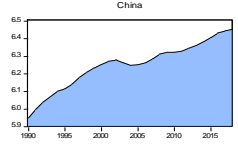

Malaysi

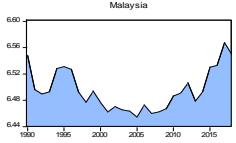

Poland

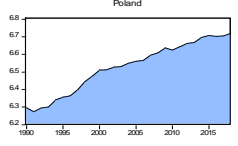

Turkey
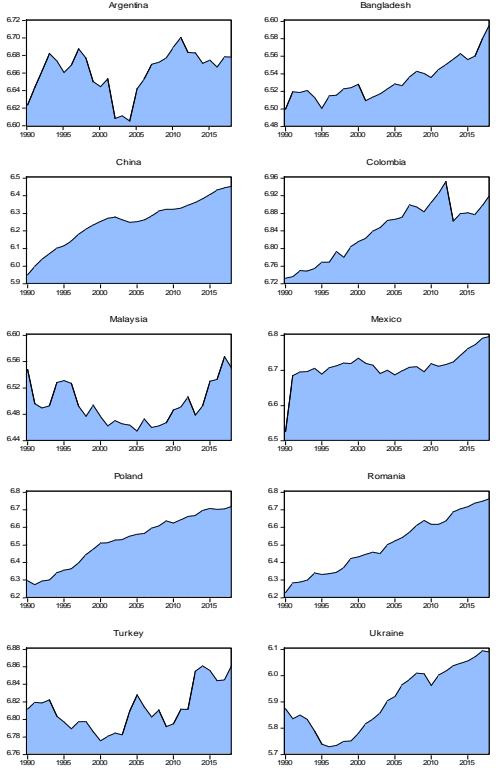

Colombia

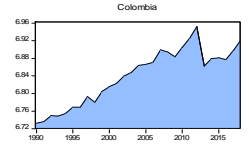

Mexico

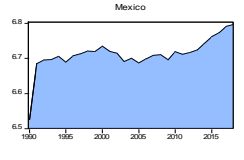

Romanis

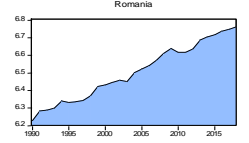

ukraine

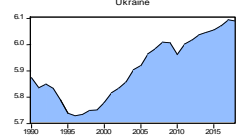

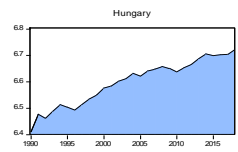

Pakisan

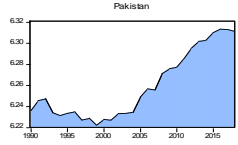

Russian Federaton

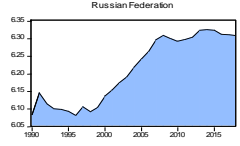

Venezuela, $\mathrm{AB}$

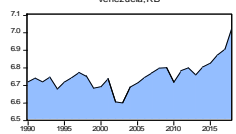

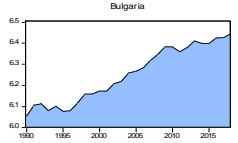

ndia

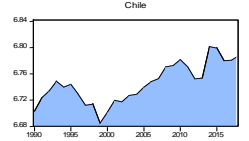

indonesia

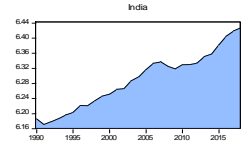

Peru

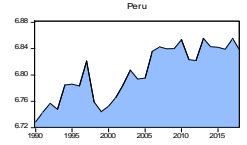

Soun Aricas
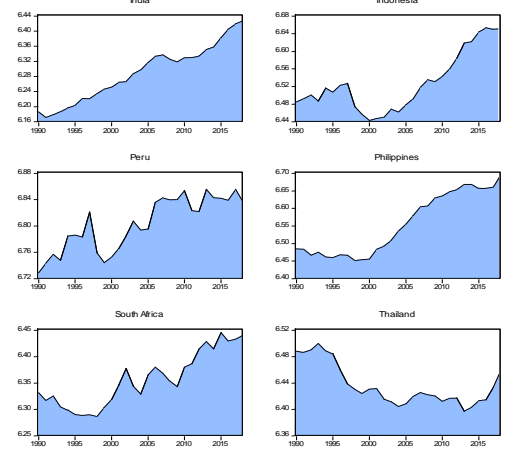

Phlippines

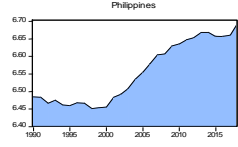

Thaland

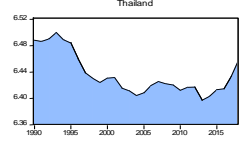

Modellerde kullanılacak olan değişkenlerin tanımı, tanımlayıcı istatistikleri, kaynakları ve değişkenlere ait özet bilgileri Tablo 1'de gösterilmiştir.

Tablo: 1

\section{Değişkenlerin Tanımı ve Kaynakları}

\begin{tabular}{|c|c|c|c|c|c|c|c|}
\hline Değișkenler & Tanım & Kaynak & NT & Ort & Std. Ht & Min. & Max. \\
\hline LEE & Log(GDP(2010 US\$ sabit fiyatlarıyla) / Toplam enerji kullanımı (ktoe)) & $\begin{array}{l}\text { GDP: Dünya Bankası } \\
\text { TES: Uluslararası Enerji } \\
\text { Ajansı }\end{array}$ & 667 & 6,517 & 0,2526 & 5,73 & 7,036 \\
\hline LCOA & Log(Kömür Fiyatları(Ton Başına US\$)) & $\begin{array}{l}\text { BP Statistical Review of } \\
\text { World Energy, (BP) }\end{array}$ & 29 & 1,748 & 0,1892 & 1,459 & 2,169 \\
\hline LOIL & Log(Ham Petrol Fiyatları (Varil Başına US\$)) & $\begin{array}{l}\text { BP Statistical Review of } \\
\text { World Energy, (BP) }\end{array}$ & 29 & 1,587 & 0,2994 & 1,104 & 2,048 \\
\hline LNAT & Log(Doğal Gaz Fiyatları (Milyon BTU başına US\$)) & $\begin{array}{l}\text { BP Statistical Review of } \\
\text { World Energy, (BP) }\end{array}$ & 29 & 0,52 & 0,2143 & 0,172 & 0,947 \\
\hline LIND & $\begin{array}{l}\text { Log(Sanayi (Madencilik, imalat, kamu hizmetleri ve inşaat), katma değeri (2010 temel } \\
\text { yılı US\$)) }\end{array}$ & World Data Bank, (WD) & 667 & 10,98 & 0,521 & 9,825 & 12,69 \\
\hline LSRV & $\begin{array}{l}\text { Log(Hizmetler (Toptan, perakende ticaret, restoranlar, oteller, Ulaşım, depolama, } \\
\text { iletișim ve Diğer faaliyetler), katma değeri ( } 2010 \text { temel yılı US\$)) }\end{array}$ & World Data Bank, (WD) & 667 & 11,18 & 0,4798 & 10,17 & 12,71 \\
\hline LAGR & Log((Tarım, avcılık, ormancılık, balıkçılık, katma değeri (2010 temel yılı US\$)) & World Data Bank, (WD) & 667 & 10,36 & 0,5341 & 9,279 & 11,89 \\
\hline LEXP & Log(Mal ve hizmet ihracatı (2010 temel yılı US\$)) & $\begin{array}{l}\text { World Data Bank, (WD) and } \\
\text { KNOEMA }\end{array}$ & 667 & 10,89 & 0,5118 & 9,111 & 12,4 \\
\hline LIMP & Log(Mal ve hizmet ithalatı (2010 temel yılı US\$)) & $\begin{array}{l}\text { World Data Bank, (WD) and } \\
\text { KNOEMA }\end{array}$ & 667 & 10,84 & 0,4876 & 9,383 & 12,37 \\
\hline LINV & Log(Brüt sabit sermaye olușumu (2010 temel yılı US\$)) & World Data Bank, (WD) & 667 & 10,8 & 0,5507 & 9,028 & 12,65 \\
\hline LFDI & Log(Doğrudan yabancı yatırımlar, net girișler (2010 temel yılı US\$)) & World Data Bank, (WD) & 667 & 1,648 & 0,0737 & $-0,028$ & 1,985 \\
\hline LOPN & $\begin{array}{l}\text { Log(Accıklık(Ticaret (2010 temel yılı US\$)) (Ticaret, olarak mal ve hizmet ithalat ve } \\
\text { ihracat toplamının gayri safi yurtiçi hasıla payı içindeki oranı))) }\end{array}$ & World Data Bank, (WD) & 667 & 1,734 & 0,2387 & 1,138 & 2,343 \\
\hline $\mathrm{LCO}_{2}$ & $\log \left(\mathrm{CO}_{2}\right.$ emisyonu (Metrik Ton $\mathrm{CO}_{2}$ eșdeğeri)) & World Data Bank, (WD) & 667 & 2,242 & 0,5548 & 1,033 & 3,979 \\
\hline LPOP & Log(Toplam Nüfus) & World Data Bank, (WD) & 667 & 7,809 & 0,5492 & 6,847 & 9,144 \\
\hline
\end{tabular}


Serilere ait değişkenler arasındaki ikili doğrusal ilişkinin derecesi ve yönü hakkında bilgi edinmek için basit korelasyon katsayıları hesaplanmış ve Tablo 2'de gösterilmiştir.

Tablo: 2

Basit Pearson Korelasyon Katsayıları

\begin{tabular}{|c|c|c|c|c|c|c|c|c|c|c|c|c|c|c|}
\hline & LEE & LCOA & LOIL & LNAT & LIND & LSRV & LAGR & LEXP & LIMP & LINV & LFDI & LOPN & $\mathrm{LCO}_{2}$ & LPOP \\
\hline \multirow[t]{2}{*}{ LEE } & 1 & & & & & & & & & & & & & \\
\hline & - & & & & & & & & & & & & & \\
\hline \multirow[t]{2}{*}{ LCOA } & 0,179 & 1 & & & & & & & & & & & & \\
\hline & 0,000 & - & & & & & & & & & & & & \\
\hline \multirow[t]{2}{*}{ LOIL } & 0,194 & 0,915 & 1 & & & & & & & & & & & \\
\hline & 0,000 & 0,000 & - & & & & & & & & & & & \\
\hline \multirow[t]{2}{*}{ LNAT } & 0,093 & 0,554 & 0,614 & 1 & & & & & & & & & & \\
\hline & 0,016 & 0,000 & 0,000 & - & & & & & & & & & & \\
\hline \multirow[t]{2}{*}{ LIND } & 0,150 & 0,198 & 0,218 & 0,125 & 1 & & & & & & & & & \\
\hline & 0,000 & 0,000 & 0,000 & 0,001 & - & & & & & & & & & \\
\hline \multirow[t]{2}{*}{ LSRV } & 0,129 & 0,254 & 0,281 & 0,147 & 0,945 & 1 & & & & & & & & \\
\hline & 0,001 & 0,000 & 0,000 & 0,000 & 0,000 & - & & & & & & & & \\
\hline \multirow[t]{2}{*}{ LAGR } & $-0,063$ & 0,114 & 0,125 & 0,067 & 0,810 & 0,793 & 1 & & & & & & & \\
\hline & 0,103 & 0,003 & 0,001 & 0,084 & 0,000 & 0,000 & - & & & & & & & \\
\hline \multirow[t]{2}{*}{ LEXP } & 0,051 & 0,336 & 0,375 & 0,256 & 0,882 & 0,832 & 0,602 & 1 & & & & & & \\
\hline & 0,191 & 0,000 & 0,000 & 0,000 & 0,000 & 0,000 & 0,000 & - & & & & & & \\
\hline \multirow[t]{2}{*}{ LIMP } & 0,016 & 0,424 & 0,465 & 0,291 & 0,836 & 0,852 & 0,662 & 0,935 & 1 & & & & & \\
\hline & 0,673 & 0,000 & 0,000 & 0,000 & 0,000 & 0,000 & 0,000 & 0,000 & - & & & & & \\
\hline \multirow[t]{2}{*}{ LINV } & 0,091 & 0,268 & 0,285 & 0,145 & 0,958 & 0,955 & 0,846 & 0,848 & 0,882 & 1 & & & & \\
\hline & 0,018 & 0,000 & 0,000 & 0,000 & 0,000 & 0,000 & 0,000 & 0,000 & 0,000 & - & & & & \\
\hline \multirow[t]{2}{*}{ LFDI } & 0,010 & 0,024 & 0,031 & 0,111 & $-0,024$ & $-0,040$ & $-0,066$ & $-0,003$ & $-0,006$ & $-0,027$ & 1 & & & \\
\hline & 0,794 & 0,544 & 0,427 & 0,004 & 0,539 & 0,300 & 0,090 & 0,933 & 0,874 & 0,492 & - & & & \\
\hline \multirow[t]{2}{*}{ LOPN } & $-0,196$ & 0,193 & 0,220 & 0,215 & $-0,204$ & $-0,284$ & $-0,359$ & 0,207 & 0,185 & $-0,199$ & 0,063 & 1 & & \\
\hline & 0,000 & 0,000 & 0,000 & 0,000 & 0,000 & 0,000 & 0,000 & 0,000 & 0,000 & 0,000 & 0,102 & - & & \\
\hline \multirow[t]{2}{*}{$\mathrm{LCO}_{2}$} & $-0,383$ & 0,125 & 0,138 & 0,082 & 0,830 & 0,842 & 0,759 & 0,789 & 0,791 & 0,843 & $-0,026$ & $-0,110$ & 1 & \\
\hline & 0,000 & 0,001 & 0,000 & 0,033 & 0,000 & 0,000 & 0,000 & 0,000 & 0,000 & 0,000 & 0,508 & 0,004 & - & \\
\hline \multirow[t]{2}{*}{ LPOP } & $-0,237$ & 0,045 & 0,052 & 0,033 & 0,667 & 0,691 & 0,914 & 0,420 & 0,519 & 0,731 & $-0,080$ & $-0,458$ & 0,718 & 1 \\
\hline & 0,000 & 0,241 & 0,180 & 0,392 & 0,000 & 0,000 & 0,000 & 0,000 & 0,000 & 0,000 & 0,039 & 0,000 & 0,000 & - \\
\hline
\end{tabular}

Not: Gözlem sayısı NT=667 olup, korelasyon katsayılarının altındaki değerler olasılık değerleridir.

Korelasyon katsayısı, -1 ile 1 arasında olup panel veri değişkenleri arasında doğrusal ilişkinin derecesini gösterir. Bu değerin mutlak değer olarak 1'e yakın olması güçlü bir ilişkinin olduğu, 0'a yakın olması ise zayıf bir ilişkinin olduğu anlamına gelir (Beaumont 2012: 8). Tarım sektörü geliri (LAGR), ticaret açığı (LOPN), $\mathrm{CO}_{2}$ emisyonu $\left(\mathrm{LCO}_{2}\right)$ ve nüfus (LPOP) hariç bütün değişkenler enerji etkinliği ile pozitif bir ilişkiye sahiptir. Tarım sektörü geliri (LAGR), ihracat (LEXP), ithalat (LIMP) ve doğrudan yabancı yatırımlar (LFDI) hariç diğer bütün değişkenler enerji etkinliği ile istatistiksel olarak anlamlıdır. Genel olarak değişkenler ile etkinlik arasında düşük bir ilişki vardır. Fakat doğrusal korelasyon katsayılarının düşük bulunması normal olmakla birlikte anlamlı bulunması kurulacak modellerin açıklayıcı gücünü artırmada avantaj sağlayacaktır.

\subsection{Varyans Büyütme Faktör Katsayıları}

Modelde kullanılacak bağımsız değişkenler arasındaki korelasyon katsayısı 0,80’den yüksek olması durumunda çok ciddi doğrusallık problemi ortaya çıkacaktır (Gujarati, 2003: 359). Ayrıca varyans büyütme faktörleri (VIF) eğer 10 değerinin üzerinde ise çoklu doğrusallık sorunu vardır denilebilir (Iddrisu \& Alagidede 2020: 7; Abbas, 2020: 8). Genel olarak Tablo 2'ye dikkat edilirse bazı bağımsız değişkenlerin kendi aralarındaki korelasyon katsayısı 0.80’nin üzerinde ve bunlar arasında bağımlı ile bağımsız arasındaki ilişkiden daha yüksek olanları vardır. Bu nedenle hipotezlerimizin veya ileri sürülen değişkenlerin enerji 
etkinliğini etkilemede anlamlı olup olmadığını kesinleştirmek için alternatif modeller kurulmuştur.

23 Yükselen Ekonomi için enerji etkinliğini etkileyen talep yanlı toplamda 9 Model oluşturulmuştur. İlk olarak korelasyon ve VIF değerlerinin dikkate alınmadığı Model1 için tüm değişkenler ve Model2 için ise sadece fiyat ve gelir değişkenleri kullanılmıştır. Diğer 7 modelde ise VIF değerleri 10'u geçmeyecek şekilde oluşturulmuş ve VIF bilgileri Tablo 3 'te gösterilmiştir.

Tablo: 3

Tüm Modellerin VIF Bilgileri

\begin{tabular}{|c|c|c|c|c|c|c|c|c|c|}
\hline Variable & Model1 & Model2 & Model3 & Model4 & Model5 & Model6 & Model7 & Model8 & Model9 \\
\hline LIND & 44,31 & 10,52 & & & & & 6,69 & & \\
\hline LEXP & 36,41 & & 7,24 & & 3,9 & & & & 3,73 \\
\hline LINV & 34,76 & & 9,05 & 4,54 & & & & & \\
\hline LIMP & 28,16 & & & & & 4,31 & 6,83 & 3,32 & \\
\hline LSRV & 25,92 & 10,34 & & & & 5,77 & & & \\
\hline LAGR & 11,76 & 3,02 & & 3,11 & & & & 8,58 & \\
\hline LPOP & 10,38 & & 4,22 & 3,19 & & 2,41 & 3,04 & 7,43 & 3,03 \\
\hline LOIL & 7,6 & 7,03 & 1,27 & & & & & & \\
\hline LOPN & 6,42 & & & 1,55 & 1,75 & & 2,53 & & 1,72 \\
\hline $\mathrm{LCO}_{2}$ & 6,33 & & 5,38 & 4,26 & 4,18 & 4,47 & 4,53 & 4,08 & 5,31 \\
\hline LCOA & 6,24 & 6,15 & 1,21 & & & & & & \\
\hline LNAT & 1,7 & 1,61 & & & 1,13 & & & & 1,15 \\
\hline LFDI & 1,04 & & & & & 1,01 & & 1,01 & \\
\hline Ortalama VIF & 17 & 6,445 & 5,42 & 2,962 & 2,814 & 3,594 & 4,724 & 4,884 & 2,988 \\
\hline
\end{tabular}

Çalışmada öncelikle korelasyon katsayılarına ve VIF değerlerine bakılmaksızın tüm değişkenlerin yer aldığ Model1 ve iktisat teorisine göre talebin en önemli belirleyicileri olan sadece fiyat ve gelirin yer aldığı Model2 oluşturulmuştur. Daha sonra çoklu doğrusal bağlantı probleminden sakınmak için değişkenler arasında; değişkenlerin Yükselen Ekonomiler'deki önemi, ikili korelasyon ve VIF katsayıları dikkate alınıp kombinasyonlar yapılarak alternatif yedi model oluşturulmuş ve tahmin edilmiştir. Oluşturulan bu yedi modelden maksat kömür ile petrol, ithalat ile ihracat, yatırım ile sanayi sektör geliri, sanayi sektör geliri ile hizmet sektör geliri gibi değişkenler arasında bulunan yüksek korelasyonun çoklu doğrusal bağlantılılık ile anlamsız parametre tahminine sebep olabileceği endişesi ile her bir değişkenin en az bir Modelde anlamlı olmasının yanında hem daha fazla bilgi alınabilmesi için kullanılacak olan değişkenlerin anlamlı olacağı maksimum değişken sayısı gözetilmiş hem de VIF değerlerinin 10'u geçmemesine dikkat edilmiştir. Oluşturulan modeller:

$$
\begin{aligned}
& \text { Model1:LEE } E_{i t}=\beta_{0}+\beta_{1} L C O A_{i t}+\beta_{2} L O I L_{i t}+\beta_{3} L N A T_{i t}+\beta_{4} L A G R_{i t}+\beta_{5} L S R V_{i t}+ \\
& \beta_{6} L I N D_{i t}+\beta_{7} L P O P_{i t}+\beta_{8} L O P N_{i t}+\beta_{9} L F D I_{i t}+\beta_{10} L I N V_{i t}+\beta_{11} L E X P_{i t}+\beta_{12} L I M P_{i t}+ \\
& \beta_{13} L C O 2_{i t}+u_{i t} \\
& \text { Model2: } L E E_{i t}=\beta_{0}+\beta_{1} L C O A_{i t}+\beta_{2} L O I L_{i t}+\beta_{3} L N A T_{i t}+\beta_{4} L A G R_{i t}+\beta_{5} L S R V_{i t}+ \\
& \beta_{6} L I N D_{i t}+u_{i t} \\
& \text { Model3:LEE } E_{i t}=\beta_{0}+\beta_{1} L C O A_{i t}+\beta_{2} L P O P_{i t}+\beta_{3} L I N V_{i t}+\beta_{4} L E X P_{i t}+\beta_{5} L C O 2_{i t}+u_{i t} \\
& \text { Model4:LEE } E_{i t}=\beta_{0}+\beta_{1} L^{L O I L} L_{i t}+\beta_{2} L P O P_{i t}+\beta_{3} L O P N_{i t}+\beta_{4} L I N V_{i t}+\beta_{5} L C O 2_{i t}+u_{i t}
\end{aligned}
$$




$$
\begin{aligned}
& \text { Model5:LEE } E_{i t}=\beta_{0}+\beta_{1} L N A T_{i t}+\beta_{2} L A G R_{i t}+\beta_{3} L O P N_{i t}+\beta_{4} L E X P_{i t}+\beta_{5} L C O 2_{i t}+u_{i t} \\
& \text { Model6:LEE } E_{i t}=\beta_{0}+\beta_{1} L S R V_{i t}+\beta_{2} L P O P_{i t}+\beta_{3} L F D I_{i t}+\beta_{4} L I M P_{i t}+\beta_{5} L C O 2_{i t}+u_{i t} \\
& \text { Model7:LEE } E_{i t}=\beta_{0}+\beta_{1} L I N D_{i t}+\beta_{2} L P O P_{i t}+\beta_{3} L O P N_{i t}+\beta_{4} L I M P_{i t}+\beta_{5} L C O 2_{i t}+u_{i t}(7) \\
& \text { Model8:LEE } E_{i t}=\beta_{0}+\beta_{1} L A G R_{i t}+\beta_{2} L P O P_{i t}+\beta_{3} L O F D I_{i t}+\beta_{4} L I M P_{i t}+\beta_{5} L C O 2_{i t}+u_{i t}
\end{aligned}
$$

$$
\text { Model9:LEE } i t=\beta_{0}+\beta_{1} L N A T_{i t}+\beta_{2} L P O P_{i t}+\beta_{3} L O P N_{i t}+\beta_{4} L E X P_{i t}+\beta_{5} L C O 2_{i t}+u_{i t}
$$

şeklindedir.

Analize geçmeden önce serilerin birim kök içerip içermediği araştırılacaktır. Bunun için öncelikle değişkenlerde birimler arası korelasyon sınanacaktır. Çünkü birimler arası korelasyonun olmaması durumunda 1 . Nesil birim kök testleri, var olması durumunda ise 2. Nesil birim kök testleri tercih edilecektir. Seriler için yatay kesit bağımlılık test sonuçları Tablo 3'de gösterilmiştir.

\subsection{Yatay Kesit Bağımlılığı Testi}

Çalışmada kullanılan veri seti hem zamana hem de birime sahip olduğu için panel tahmin yöntemlerinden yararlanılacaktır. Aynı zamanda zaman boyutunun birim boyutundan büyük olduğu için veri makro panel özelliğine sahiptir. Son dönemde panel veri seti modellemelerinin kullanıldığı analizlerde birim kök analizi yapılmadan önce kesitler arası korelasyona veya bir diğer ifadeyle yatay kesit bağımlılığına bakılmaktadır. Çünkü yatay kesit bağımlılığına bakılması, gözlemlenemeyen ortak etkilerin incelenmesini ve kullanılacak tahmin yönteminin belirlenmesini ve dolayısıyla elde edilecek katsayıların ve standart hataların güvenirliğini belirleyecektir. İktisadi olarak ise bir ülkede ortaya çıkan makroekonomik bir şokun diğer ülkeleri de etkileyip etkilemediğine karar vermek için yatay kesit bağımlılığı testlerinden faydalanılmaktadır (Özbek, 2020: 245). Bu yüzden yöntem olarak öncelikle kesitler arası korelasyon testleri yapılarak kullanılacak olan durağanlık testleri ve tahmincilere karar verilecektir.

Literatürde panel tahmin yöntemlerinin kullanıldığı çalışmalara dikkat edilirse, yatay kesit bağımlılığını sınamak için ve $\mathrm{T}>\mathrm{N}$ birim şeklinde verilerde Breusch-Pagan (1980) CDLM1 testi ve Pesaran (2004) CDLM2 testlerine başvurulmaktadır (Hepaktan \& Çınar, 2011: 142). Diğer taraftan, Pesaran (2004) CDLM testi N ve T'nin yeterince büyük olduğu durumlarda yatay kesit bağımlılı̆̆ı için kullanılabilmektedir. Ancak Pesaran (2004) CDLM testi bireysel ortalamalar sıfırdan faklı ve grup ortalaması sıfır olduğundan sapmalı sonuçlar verebilir. Bunun üzerine, Peseran vd. (2008), CDLM-Adj testini geliştirmiş; Pesaran (2004) CDLM test istatistiğine ortalamayı ve varyansı birlikte ekleyerek CDLM testini düzeltmeyi başarmıştır. Bundan dolayı, bu test sapması düzeltilmiş LM testi olarak ifade edilmiştir (Göçer vd., 2012: 456). Dolayısıyla T>N koşuluna sahip bu bölüm de değişkenlerde yatay kesit bağımlılığının varlığı CDLM1 (Breusch-Pagan, 1980), CDLM2 (Pesaran, 2004) ve 
CDLM-Adj (Pesaran vd., 2008) testleri ile sinanmaktadır. Bu testlere ait $\mathrm{H}_{0}$ hipotezi $\operatorname{cov}\left(\varepsilon_{i t} \varepsilon_{j t}\right)=0$, Hata terimleri birimlere göre eş zamanlı korelasyonlu değildir Şeklindedir. Burada $\mathrm{H}_{0}$ hipotezi birimlerin hata terimleri arasında korelasyonun bulunmadığıdır. Birimlere ait yatay kesit bağımlılı̆̆ı sonuçları Tablo 4'te verilmiştir.

Tablo: 4

\section{Yatay Kesit Bağımlılı̆̆ı Test Sonuçları}

\begin{tabular}{|c|c|c|c|c|c|c|}
\hline \multirow{2}{*}{ Değiş̧kenler } & \multicolumn{2}{|c|}{ CDLM1 } & \multicolumn{2}{|c|}{ CDLM2 } & \multicolumn{2}{|c|}{ CDLM-Adj } \\
\hline & Sabitli & Sabitli ve Trendli & Sabitli & Sabitli ve Trendli & Sabitli & Sabitli ve Trendli \\
\hline LEE & $374,467 * * *$ & $374,23 * * *$ & $5,40 * * *$ & $5,39 * * *$ & $20,46^{* * * *}$ & $20,34 * * *$ \\
\hline LIND & $387,29 * * *$ & $414,43 * * *$ & $5,97 * * *$ & 7,17 *** & $6,84 * * *$ & $6,33 * * *$ \\
\hline LSRV & $380,58 * * *$ & $385,83 * * *$ & $5,67 * * *$ & $5,91 * * *$ & $7,20 * * *$ & $7,82^{* * *}$ \\
\hline LAGR & $359,32 * * *$ & $369,07 * * *$ & $4,73 * * *$ & $5,16^{* * * *}$ & $8,24 * * *$ & $8,54 * * *$ \\
\hline LEXP & $323,60 * * *$ & $345,12 * * *$ & $3,14 * * *$ & 4,10 **** & $3,35 * * *$ & $2,86^{* * * *}$ \\
\hline LIMP & $403,22 * * *$ & $414,20 * * *$ & $6,68 * * *$ & 7,17 *** & 0,69 & $1,32 *$ \\
\hline LINV & $432,05 * * *$ & $468,00 * * *$ & $7,96 * * *$ & $9,56^{* * * *}$ & $5,43 * * *$ & $5,83^{*} * *$ \\
\hline LFDI & $340,86^{* * *}$ & $354,82 * * *$ & $3,91 * * *$ & $4,53 * * *$ & $-0,76$ & $-1,08$ \\
\hline LOPN & $404,67 * * *$ & $476,16^{* * *}$ & $6,74 * * *$ & $9,92 * * *$ & $-0,35$ & $-0,38$ \\
\hline $\mathrm{LCO}_{2}$ & $363,98 * * *$ & $388,69 * * *$ & $4,93 * * *$ & 6,03 *** & $2,88 * * *$ & $3,36 * * *$ \\
\hline LPOP & $955,43 * * *$ & $903,68 * * *$ & $31,23 * * *$ & $28,93 * * * *$ & $13,94 * * *$ & $13,10 * * *$ \\
\hline
\end{tabular}

Not: *(\%10),**(\%5),***(\%1) düzeyinde anlamlllik seviyeleridir.

Tablo 4 incelendiğinde diğer değişkenler için yatay kesit bağımlılığı testlerinden CDLM1, CDLM2 ve CDLM-Adj testlerine ait bulgular gösterilmiştir. CDLM1 ve CDLM2 testlerine göre tüm değişkenlerde, "sabitli" ile "sabitli ve trendli" modellerin hepsinde yatay kesit bağımlılığı vardır. Dolayısıyla enerji fiyatları hariç diğer tüm değişkenler için 2. Nesil birim kök testleri kullanılacaktır.

\subsection{Değişkenlerin Durağanlık Testi}

Panel tahmin yöntemlerinde durağan serilerle çalışmamak sahte regresyona sebep olabilir ve tahmin sonuçlarının güvenirliğini azaltabilir (Ağır vd., 2020: 61). Bu yüzden serilerin durağanlığı ve hangi durağanlık testlerinin seçileceği önem kazanmaktadır. Gerçekte her ülke için 29 yıl boyunca aynı olan; dünya kömür fiyatları (LCOA), ham petrol fiyatları (LOIL) ve doğalgaz fiyatları (LNAT) değişkenleri için 1. Nesil birim kök testlerinden LLC (Levin, Lin \& Chu, 2002), IPS (Im, Pesaran \& Shin, 2003), Fisher-ADF ve Fisher-PP testleri kullanılacaktır (Da Silva vd., 2018: 50). Diğer değişkenler için ise ikinci nesil birim kök testlerinden Pesaran (2007) tarafından geliştirilen CIPS (Cross-sectionally Augmented IPS) ve Bai \& Ng (2010) tarafından geliştirilen PANIC (Panel Analysis of Nonstationarity in Idiosyncratic and Common Components) durağanlık testleri kullanılacaktır. Tablo 5 ve Tablo 6'da panel birim kök test sonuçları görülmektedir.

Tablo 5 incelendiğinde LCOA IPS ve Fisher-ADF testlerine göre sabitli ve trendli modellerde, LNAT ise LLC ve IPS test sonuçlarına göre sabitli modellerde düzey değerlerinde durağandır. Tablo 6 incelendiğin de ise CIPS testine göre LEE hariç tüm değişkenler sabitli, LSRV $\mathrm{Pa}$ ve $\mathrm{Pb}$ testine göre sabitli, LINV $\mathrm{Pa}, \mathrm{Pb}$ ve CIPS testine göre sabit ve trendli, LFDI Pa testine göre sabitli ve trendli, $L O P N$ ise $\mathrm{Pa}, \mathrm{Pb}$ ve PMSB testlerine göre sabitli ve trendli modellerde düzeyde durağandır. Dolayısıyla LINV ve LOPN düzeyde, enerji fiyatlarının tümü ve diğer değişkenler fark alındıktan sonra durağan hale gelmektedir. 
Tablo: 5

Birim Kök Test Sonuçları

\begin{tabular}{|c|c|c|c|c|c|c|c|c|}
\hline \multirow{2}{*}{ DÜZEY } & \multicolumn{2}{|r|}{ LLC } & \multicolumn{2}{|r|}{ IPS } & \multicolumn{2}{|c|}{ Fisher ADF } & \multicolumn{2}{|c|}{ Fisher-PP } \\
\hline & Sabitli & Sabit ve Trendli & Sabitli & Sabit ve Trendli & Sabitli & Sabit ve Trendli & Sabitli & Sabit ve Trendli \\
\hline LCOA & 0,603 & 0,924 & 0,279 & $-2,566 * * *$ & 28,952 & $59,223^{*}$ & 20,197 & 57,914 \\
\hline LOIL & 0,658 & 1,725 & 3,354 & 1,302 & 11,819 & 23,061 & 12,230 & 29,745 \\
\hline LNAT & $-3,845^{* * * *}$ & $-1,053$ & $-2,540 * * *$ & 2,306 & 57,479 & 16,868 & 50,766 & 12,369 \\
\hline FARK & & & & & & & & \\
\hline$\triangle L C O A$ & $-20,292 * * *$ & $-15,939 * * *$ & $-21,484 * * *$ & $-18,472^{* * * *}$ & $429,997 * * * *$ & $335,394 * * * *$ & $723,467 * * *$ & $680,890^{* * * *}$ \\
\hline$\triangle L O I L$ & $-16,800^{* * * *}$ & $-13,773^{* * * *}$ & $15,235^{* * * *}$ & $-12,061 * * *$ & $285,753 * * *$ & $205,601 * * *$ & $277,513 * * *$ & $196,060 * * *$ \\
\hline$\triangle L N A T$ & $-27,529 * * *$ & $-15,463 * * *$ & $-26,327 * * *$ & $-20,189^{* * * *}$ & $522,600 * * *$ & $368,621 * * *$ & 525,520 **** & $2304,36^{* * * *}$ \\
\hline
\end{tabular}

Not: *(\%10), **(\%5), ***(\%1) düzeyinde anlamlllk seviyeleridir.

Tablo: 6

Birim Kök Test Sonuçları

\begin{tabular}{|c|c|c|c|c|c|c|c|c|}
\hline & \multicolumn{2}{|r|}{$\mathbf{P a}$} & \multicolumn{2}{|r|}{$\mathbf{P b}$} & \multicolumn{2}{|r|}{ PMSB } & \multicolumn{2}{|r|}{ CIPS } \\
\hline DÜZEY & Sabitli & Sabitli ve Trendli & Sabitli & Sabitli ve Trendli & Sabitli & Sabitli ve Trendli & Sabitli & Sabitli ve Trendli \\
\hline LEE & $-0,404$ & 0,980 & $-0,446$ & 1,129 & 0,800 & 1,301 & $-1,865$ & $-2,333$ \\
\hline LIND & $-0,446$ & 0,681 & $-0,445$ & 0,775 & 0,090 & 0,841 & $-2,487 * * *$ & $-2,552$ \\
\hline LSRV & $-1,792 * *$ & 1,075 & $-1,594^{*}$ & 1,314 & $-0,486$ & 1,565 & $-2,699 * * *$ & $-2,257$ \\
\hline LAGR & 2,268 & $-0,686$ & 4,046 & $-0,643$ & 6,990 & $-0,454$ & $-2,467 * * *$ & $-2,222$ \\
\hline LEXP & 0,020 & 1,318 & 0,022 & 1,629 & 0,709 & 1,983 & $-2,185 * *$ & $-2,519$ \\
\hline LIMP & $-0,002$ & 0,600 & $-0,002$ & 0,659 & 0,839 & 0,715 & $-2,352 * * *$ & $-2,391$ \\
\hline LINV & $-0,038$ & $-2,063^{* *} *$ & $-0,035$ & $-1,628^{*}$ & $-0,184$ & $-1,134$ & $-2,496 * * *$ & $-2,622^{*}$ \\
\hline LFDI & $-0,450$ & $-1,381^{*}$ & $-0,379$ & $-1,017$ & $-0,275$ & $-0,666$ & $-2,057 *$ & $-2,304$ \\
\hline LOPN & $-1,192$ & $-3,007 * * *$ & $-0,995$ & $-2,354 * * *$ & $-0,799$ & $-1,589^{*}$ & $-2,132 *$ & $-2,506$ \\
\hline $\mathrm{LCO}_{2}$ & 1,705 & 0,856 & 2,432 & 0,959 & 3,832 & 1,113 & $-2,151 * *$ & $-2,077$ \\
\hline \multirow[t]{2}{*}{ LPOP } & 2,260 & $-0,690$ & 4,038 & $-0,647$ & 6,982 & $-0,458$ & $-1,456^{* * * *}$ & $-1,942$ \\
\hline & \multicolumn{2}{|r|}{$\mathbf{P}_{\mathrm{a}}$} & \multicolumn{2}{|r|}{$\mathbf{P}_{\mathrm{b}}$} & \multicolumn{2}{|r|}{$\mathbf{P}_{\mathrm{MSB}}$} & \multicolumn{2}{|r|}{ CIPS } \\
\hline FARK & Sabitli & Sabitli ve Trendli & Sabitli & Sabitli ve Trendli & Sabitli & Sabitli ve Trendli & Sabitli & Sabitli ve Trendli \\
\hline$\Delta \mathbf{L E E}$ & $-4,887 * * * *$ & $-8,263 * * *$ & $-2,697 * * *$ & $-4,565 * * *$ & $-1,493 *$ & $-1,902 * *$ & $-3,165 * * *$ & $-3,177 * * *$ \\
\hline$\Delta$ LIND & $-8,626^{* * * *}$ & $-8,687 * * * *$ & $-4,407 * * *$ & $-4,922 * * *$ & $-2,071 * *$ & $-2,130 * *$ & $-2,954 * * *$ & $-2,929 * * *$ \\
\hline$\Delta$ LSRV & $-33,400^{* * * *}$ & $-33,017$ **** & $-8,808^{* * * *}$ & $-13,584 * * *$ & $-2,238 * *$ & $-3,369 * * *$ & $-2,547 * * *$ & $-2,770^{* *} *$ \\
\hline$\Delta$ LAGR & $-33,977 * * *$ & $-26,375 * * *$ & $-8,216^{* * * *}$ & $-11,800^{* * * *}$ & $-1,745 * *$ & $-2,800 * * *$ & $-3,809 * * *$ & $-4,077 * * *$ \\
\hline$\Delta$ LEXP & $-3,543^{* * *} *$ & $-3,730 * * *$ & $-2,430 * * *$ & $-2,663 * * *$ & $-1,309^{*}$ & $-1,526^{*}$ & $-3,755 * * *$ & $-3,888 * * *$ \\
\hline$\Delta$ LIMP & $-2,292 * *$ & $-0,722$ & $-1,711 * *$ & $-0,656$ & $-0,956$ & $-0,441$ & $-3,293 * * *$ & $-3,386^{* * * *}$ \\
\hline$\Delta$ LINV & $-34,704 * * *$ & $-22,731 * * *$ & $-8,696 * * *$ & $-8,085 * * *$ & $-2,027 * *$ & $-1,785 * *$ & $-3,093 * * *$ & $-3,167 * * *$ \\
\hline$\Delta$ LFDI & $-24,817 * * *$ & $-1,437^{*}$ & $-6,146 * * *$ & $-1,074$ & $-1,294 *$ & $-0,633$ & $-3,474 * * *$ & $-3,407 * * *$ \\
\hline$\Delta \mathrm{LOPN}$ & $-46,324 * * *$ & $-29,492 * * *$ & $-12,037 * * *$ & $-12,419 * * *$ & $-2,625 * * *$ & $-3,038 * * *$ & $-4,053 * * *$ & $-4,160$ **** \\
\hline$\Delta \mathrm{LCO}_{2}$ & $-30,073 * * *$ & $-27,731 * * *$ & $-8,615 * * *$ & $-11,207 * * * *$ & $-2,318 * *$ & $-2,821 * * *$ & $-2,969 * * *$ & $-3,148$ *** \\
\hline$\Delta$ LPOP & $-33,969 * * *$ & $-26,380 * * *$ & $-8,208 * * *$ & $-11,804 * * *$ & $-1,737 * *$ & $-2,804 * * *$ & $-2,259 * *$ & $-3,323^{* * *}$ \\
\hline
\end{tabular}

Not: *(\%10), **(\%5), ***(\%1) düzeyinde anlamlılık seviyeleridir.

\subsection{Modellerde Yatay Kesit Bağımlıı̆ı̆ı ve Eğim Parametrelerinde Homojenlik Testleri}

Panel tahmin yöntemlerinin avantajlarından birisi eğim parametrelerinin Homojenlik varsayımı altında birim ve zaman boyutundan gelen bilgileri havuzlandırmasıdır. Pesaran vd. (1996) birim boyutunun zaman boyutundan büyük olduğu durumda Hausman (1978) tipi testini önermiştir. Bu testte eğim parametrelerinin homojenlik ve heterojenlik durumuna göre sabit etkiler tahmincisi ve ortalama grup tahmincilerini kıyaslamaktadır. Bunun tersine zaman boyutunun birim boyutundan büyük olduğu durumlarda ise Swamy (1970) Havuzlanmış En Küçük Kareler (POLS) sonuçlarından elde edilen birimlere ait katsayıları kullanarak kendi Swamy testini önermiştir. Pesaran \& Yamagata (2008) model hatalarının her durumda normal dağılım göstermezse bile elde edilen istatistik değerlerinin normal dağılım gösterdiği 


$$
\begin{aligned}
& \tilde{\Delta}=\sqrt{N}\left(\frac{N^{-1} \check{S}-k}{\sqrt{2 k}}\right) \\
& \tilde{\Delta}_{a d j}=\sqrt{\frac{N(T+1)}{T-k-1}}\left(\frac{N^{-1} S-k}{\sqrt{2 k}}\right)
\end{aligned}
$$

şeklinde test geliştirmişlerdir. Bu testi geliştirirken ve aynı zamanda formülde de bulunan $\breve{S}$, Swamy test istatistiğini modifiye etmişlerdir.

Ayrıca modellerde yatay kesit bağımlılık sınanacaktır. Eğer modellerde yatay kesit bağımlılı̆̆1 yoksa 1. Nesil eşbütünleşme testleri, var ise 2. Nesil eşbütünleşme testleri kullanılacaktır (Özbek \& Türkmen, 2020: 2106). Ayrıca kullanılacak tahmin yönteminin özelliğini belirleyecek olan eğim parametrelerinin homojenliği veya heterojenliği her bir model için test edilmiş ve Tablo 7'de gösterilmiştir.

Tablo: 7

Modellerde Yatay Kesit Bağımlılığı ve Eğim Parametrelerinde Homojenlik Test

\begin{tabular}{|c|c|c|c|c|c|c|}
\hline \multirow{2}{*}{ Modeller } & \multicolumn{4}{|c|}{ Yatay Kesit Bağımlılığı Testleri } & \multicolumn{2}{|c|}{ Homojenlik Testleri } \\
\hline & CD $_{\text {LM1 }}$ & $\mathrm{CD}_{\mathrm{LM} 2}$ & $\mathbf{C D}_{\mathrm{LM}}$ & CD $_{\text {LMadj }}$ & $\tilde{\Delta}$ & $\tilde{\Delta}_{a d j}$ \\
\hline Madel1 & $347,959 * * *$ & $4,221 * * *$ & $2,583^{* * *}$ & $-0,681$ & $10,023 * * *$ & $14,175 * * *$ \\
\hline Model2 & $515,801 * * *$ & $11,683 * * *$ & $1,317 *$ & $17,030 * * *$ & $20,845^{* * *}$ & $24,342 * * *$ \\
\hline Model3 & $354,921 * * *$ & $4,531 * * *$ & 1,274 & $8,593 * * *$ & $23,835 * * *$ & $27,211 * * *$ \\
\hline Model4 & $336,289 * * *$ & $3,703^{* * *} *$ & $1,803 * *$ & $4,441 * * *$ & $24,651 * * *$ & 28,153 *** \\
\hline Model5 & $455,288 * * *$ & $8,993 * * *$ & $2,617 * * *$ & $14,198 * * *$ & $23,140 * * *$ & $26,428 * * *$ \\
\hline Model6 & $367,734 * * *$ & $5,101 * * *$ & $-1,314^{*}$ & $5,497 * * *$ & $23,596 * * *$ & $26,949 * * *$ \\
\hline Model7 & $361,313^{* * * *}$ & $4,815^{* * *}$ & $1,890^{* * *}$ & $6,613 * * *$ & 23,631 *** & $26,988^{* * * *}$ \\
\hline Model8 & $417,847^{* * * *}$ & $7,328 * * *$ & $5,377^{* * * *}$ & $7,399 * * *$ & $24,481 * * *$ & $27,959 * * *$ \\
\hline Model9 & $515,434 * * *$ & $11,667 * * *$ & $4,875^{\text {**** }}$ & $8,972 * * *$ & $24,498 * * *$ & 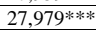 \\
\hline
\end{tabular}
Sonuçları

Not: *(\%10), **(\%5), ***(\%1) düzeyinde anlamlilik seviyeleridir.

Tablo 7'ye dikkat edilirse tüm modellerde hem yatay kesit bağımlılığı hem de eğim parametrelerinin heterojen olduğu görülmektedir. Bundan sonraki adımlarda bu durumlar dikkate alınarak tahminler yapılacaktır.

\subsection{Eşbütünleşme Testi}

Zaman boyutunun birim boyutundan büyük olduğu panellere makro paneller denilmektedir. Bu paneller uzun dönem ilişkisine sahip olabilmektedir. Dolayısıyla veri seti makro panellere uygun olan bu bölümde model içerisinde yatay kesit bağımlılı̆̆ bulunduğundan dolayı ikinci nesil panel eşbütünleşme testlerinden Durbin-Hausman eşbütünleşme testi kullanılmıştır. Westerlund (2008)'in geliştirdiği bu test modelde kalıntılar üzerinden faktör ayrıştırması yaparak yatay kesit bağımlılığının bulunduğu durumda eşbütünleşme ilişkisi araştırmaktadır. Ayrıca test, bağımlı değişkenin I(1), açıklayıcı değişkenlerin ise eşbütünleşme derecesinin önemli olmadiğı durumda eşbütünleşme ilişkisini araştırabilmektedir. Durbin-Hausman eşbütünleşme testinin genel denklemi

$$
y_{i t}=\beta_{i} x_{i t}+\alpha_{i}^{\prime} \delta_{t}+u_{i t}, x_{i t}=\gamma_{i} x_{i t-1}+\varepsilon_{i t}
$$


şeklindedir (Sahabi, 2020: 81). Denklemdeki $\delta_{t}$ deterministik terimleri ifade etmektedir. Eğer $\delta_{t}=(1)$ ise model sabitli $\delta_{t}=(1, t)$ iken model sabitli ve trendli halini almaktadır. Açıklayıcı değişken için ise Dickey-Fuller (DF) fonksiyonunda $\gamma_{i}=1\left(x_{i t} \sim I(1)\right)$ şeklinde bir gereklilik şartı yoktur. Durbin-Hausman eşbütünleşme testi için $\mathrm{H}_{0}$ hipotezi Eşbütünleşme İlişkisi Yok şeklindedir. Bu hipotez testlerinin test edilmesi için Choi (1994) tarafından elde edilen test istatistikleri kullanılmaktadır. Durbin-Hausman test istatistiği ise

$$
\begin{aligned}
& D H g=\sum_{i=1}^{N} \hat{S}_{i}\left(\hat{\rho}_{i, O L S}-\hat{\rho}_{i, I V}\right)^{2} \sum_{t=2}^{T} \hat{e}_{i t-1}^{2} \\
& \left.D H p=\hat{S}_{N} \widehat{\rho}_{O L S}-\hat{\rho}_{I V}\right)^{2} \sum_{i=1}^{N} \sum_{t=2}^{T} \hat{e}_{i t-1}^{2}
\end{aligned}
$$

şeklinde hesaplanmaktadır (Altıntaş \& Mercan, 2015: 368). Burada DHp, modelin eğim parametrelerinin homojen olduğu için panel istatistiğini verirken $\mathrm{DHg}$ ise eğim parametrelerinin heterojen olduğu durumda grup istatistiğini vermektedir. Dolayısıyla modellerde uzun dönem ilişki olup olmadığını araştırmak için eşbütünleşme testi yapılacaktır. Modellerde yatay kesit bağımlılı̆̆ının bulunması ve eğim parametrelerinin heterojenliği ayrıca bağımlı değişkenin birinci farkta açıklayıcı değişkenlerin ise farklı düzeylerde durağan olması dikkate alındığında 2. Nesil eşbütünleşme testlerinden DurbinHausman (Westerlund, 2008) testi kullanılacaktır. Durbin-Hausman eşbütünleşme test sonuçları Tablo 8'de gösterilmiştir.

Tablo: 7

\begin{tabular}{|c|c|c|c|c|}
\hline \multirow{2}{*}{ Modeller } & \multicolumn{2}{|c|}{$\mathrm{DH}_{\mathrm{G}}$} & \multicolumn{2}{|c|}{ DHP } \\
\hline & Sabitli & Sabit ve Trendli & Sabitli & Sabit ve Trendli \\
\hline Madel1 & $3,268 * * *$ & $1,763^{* *}$ & $-1,402$ & $3,597 * * *$ \\
\hline Madel2 & 0,160 & $4,143^{* * * *}$ & $-1,464$ & $8,472 * * *$ \\
\hline Madel3 & $-1,224$ & $10,935 * * *$ & $-1,815$ & $7,161 * * *$ \\
\hline Madel4 & $-0,667$ & $4,128 * * *$ & $-1,397$ & $5,537 * * *$ \\
\hline Madel5 & $-0,248$ & $8,380 * * *$ & $-1,307$ & $7,753 * * *$ \\
\hline Madel6 & $14,211^{* * * *}$ & $11,118^{* * * *}$ & $-1,167$ & $-3,810$ \\
\hline Madel7 & $1,385^{*}$ & $3,732 * * *$ & $2,109^{* * *}$ & $-2,049^{* *}$ \\
\hline $\begin{array}{l}\text { Madel8 } \\
\end{array}$ & $5,759 * * *$ & $-0,713$ & $-1,489$ & $-3,855$ \\
\hline Madel9 & $-0,269$ & $8,706 * * *$ & $-1,357$ & $7,577 * * * *$ \\
\hline
\end{tabular}

Modellerde Durbin-Hausman Eşbütünleşme Test Sonuçları

Not: *(\%10), **(\%5), ***(\%1) düzeyinde anlamlllk seviyeleridir.

Durbin - Hausman eşbütünleşme testi hem grup $\left(\mathrm{DH}_{\mathrm{G}}\right)$ hem de panel $\left(\mathrm{DH}_{\mathrm{P}}\right)$ istatistik sonuçlarını vermektedir. Eğer eğim parametreleri homojen ise $\mathrm{DH}_{\mathrm{P}}$ panel istatistiği, heterojen ise $\mathrm{DH}_{\mathrm{G}}$ grup istatistiği kullanılacaktır. Tablo 6'ya dikkat edilirse tüm modellerde eğim parametrelerinin heterojen olduğu görülmektedir. Dolayısıyla tüm modeller için grup istatistiği olan $\mathrm{DH}_{\mathrm{G}}$ değeri kullanılacaktır. Ayrıca Tablo 7'ye bakılırsa tüm modeller için eşbütünleşme ilişkisinin var olduğu görülmektedir. Dolayısıyla tüm modeller için enerji etkinliği ile açıklayıcı değişkenler arasında uzun dönemli bir ilişki bulunduğu sonucu elde edilmektedir. Bu yüzden bundan sonraki adımda tüm modeller için enerji etkinliği ile açıklayıcı değişkenler arasında uzun dönemli ilişki araştırılacaktır.

$\mathrm{Bu}$ bulgular doğrultusunda, enerji etkinliği ile açıklayıcı değişkenler arasında uzun dönem katsayılarının tahmini CCEMG (Common Correlated Effects Mean Group estimator, 
heterojen eğim tahmini ve $\mathrm{T}>\mathrm{N}$ için uygun) tahmin yöntemi ile araştırılmıştır. CCEMG tahmin sonuçlarının güvenirliğini artırmak için AMG (Augmented Mean Group estimator, heterojen eğim tahmini ve kesit bağımlılık durumunda uygun) ikinci tahmin yöntemi olarak kullanılmıştır. Hem CCEMG hem de AMG tahmin yöntemleri hem modeller arasında yatay kesit bağımlılığının bulunduğu hem de eğim parametrelerinin heterojen olduğu durumda kullanılabilmektedir.

\subsection{Model Tahmin Tekniği}

Eşbütünleşme testinden sonra enerji etkinliği ile açıklayıcı değişkenler arasında uzun dönem katsayılarının tahmini Pesaran (2006) tarafından geliştirilen CCEMG (Common Correlated Effects Mean Group estimator, heterojen eğim tahmini ve $\mathrm{T}>\mathrm{N}$ için uygun) tahmin yöntemi ile araştırılmıştır. CCEMG tahmin sonuçlarının güvenirliğini artırmak için ise (Eberhardt \& Bond, 2009; Eberhardt \& Teal, 2010) tarafından geliştirilen Genişletilmiş ortalama grup (AMG) tahmincileri kullanilacaktır. AMG (Augmented Mean Group estimator, heterojen eğim tahmini ve kesit bağımlılık durumunda uygun) ikinci tahmin yöntemi olarak kullanılmıştır.

$$
\begin{aligned}
& \text { Pesaran CCEMG'yi } \\
& y_{i t}=a_{i} d_{t}+\beta_{k i} x_{k i t}+u_{i t}, u_{i t}=\gamma_{i m} \mathrm{H}_{t m}+\varepsilon_{i t}
\end{aligned}
$$

şeklindeki genel panel denklemini genişletip $\mathrm{N}$ tane grup regresyonu yaparak elde etmiştir. Her bir kesit için

$$
y_{i t}=a_{i} d_{t}+\beta_{k i} x_{k i t}+\theta_{1 i} \bar{y}_{t}+\theta_{2 i} \bar{x}_{k t}+u_{i t}
$$

şeklinde model tahmin edilir. Pesaran bu denklemde hatalar arasındaki ilişkiye sebep olan ve $\mathrm{H}_{t}$ ortak gözlemlenemeyen faktörler yerine bağımlı ve açıklayıcı değişkenlerin yatay kesitleri ile genişletmiş ve heterojenlik altında her bir eğim parametresi için

$$
\beta_{i}=\beta+v_{i}
$$

şeklinde rassal sürecin bulunduğunu varsaymaktadır. Ortalama etki ise bu katsayıları N'e bölerek, yani aritmetik ortalaması alınarak

$$
\hat{\beta}_{C C E M G}=N^{-1} \sum_{i}^{N} \hat{\beta}_{i}
$$

şeklinde hesaplanmaktadır. Benzer şekilde Eberhardt \& Bond (2009) ve Eberhardt \& Teal (2010) tarafından geliştirilen Genişletilmiş Ortalama Grup (AMG) tahmincilerinde yatay kesit ortalamalarını dikkate almaktadır. Bunu ise gözlemlenemeyen ortak faktörleri dikkate alarak değişkenlerin yatay kesit ortalamaları yerine AMG ortak dinamik etkileri dâhil ederek yapmaktadır. AMG de öncelikle kukla değişkenleri modele dâhil ederek

$$
\Delta y_{i t}=\beta \Delta x_{i t}+\sum_{t=2}^{T} c_{i} \Delta D_{t}+u_{i t}
$$


şeklinde farkı alınmış POLS tahmini yapılmaktadır. Sonra ortak dinamik süreç $\left(\hat{c}_{t} \equiv \hat{u}_{t}^{*}\right)$ bağımlı değişkenden çıkarılarak veya eklenerek her kesit için

$$
\begin{aligned}
& y_{i t}-\hat{u}_{t}^{*}=a_{i}+\beta_{i} x_{i t}+u_{i t} d_{i} x_{i t} \\
& y_{i t}=a_{i}+\beta_{i} x_{i t}+d_{i} \hat{u}_{t}^{*}+u_{i t}
\end{aligned}
$$

şeklinde tahmin yapılır. Son olarak tahmin edilen modelde eğim parametreleri

$$
\hat{\beta}_{A M G}=N^{-1} \sum_{i}^{N} \hat{\beta}_{i}
$$

şeklinde N'e bölünerek aritmetik ortalaması alınır.

CCEMG ve AMG tahmincilerine ait sonuçlar Tablo 8 ve Tablo 9'da görülmektedir.

\begin{tabular}{|c|c|c|c|c|c|c|c|c|c|}
\hline LEE & Model1 & Model2 & Model3 & Model4 & Model5 & Model6 & Model7 & Model8 & Model9 \\
\hline \multirow[t]{2}{*}{ LCOA } & $-0,005$ & $-0,003$ & $-0,013$ & & & & & & \\
\hline & 0,025 & 0,015 & 0,011 & & & & & & \\
\hline \multirow[t]{2}{*}{ LOIL } & 0,013 & 0,002 & & $-0,006$ & & & & & \\
\hline & 0,024 & 0,012 & & 0,011 & & & & & \\
\hline \multirow[t]{2}{*}{ LNAT } & $-0,024 * *$ & 0,001 & & & 0,002 & & & & $-0,003$ \\
\hline & 0,010 & 0,012 & & & 0,008 & & & & 0,003 \\
\hline \multirow[t]{2}{*}{ LAGR } & $-0,120$ & 0,014 & & & $0,140 * *$ & & & 0,091 & \\
\hline & 0,118 & 0,109 & & & 0,071 & & & 0,100 & \\
\hline \multirow[t]{2}{*}{ LSRV } & 0,216 & 0,090 & & & & 0,303 **** & & & \\
\hline & 0,169 & 0,117 & & & & 0,092 & & & \\
\hline \multirow[t]{2}{*}{ LIND } & 0,316 & 0,186 & & & & & $0,327 * *$ & & \\
\hline & 0,200 & 0,119 & & & & & 0,133 & & \\
\hline \multirow[t]{2}{*}{ LPOP } & $-1,120$ & & $-1,905$ & $-0,633$ & & $-2,235^{*}$ & $-0,369$ & $-1,450$ & $-2,071$ \\
\hline & 1,759 & & 1,317 & 0,982 & & 1,331 & 1,089 & 0,906 & 1,324 \\
\hline \multirow[t]{2}{*}{ LOPN } & 0,040 & & & $-0,015$ & $-0,083^{*} * *$ & & $-0,070 * * *$ & & $-0,114 * * *$ \\
\hline & 0,092 & & & 0,025 & 0,028 & & 0,024 & & 0,034 \\
\hline \multirow[t]{2}{*}{ LFDI } & 0,126 & & & & & 0,010 & & 0,049 & \\
\hline & 0,109 & & & & & 0,058 & & 0,069 & \\
\hline \multirow[t]{2}{*}{ LINV } & 0,014 & & 0,123 **** & $0,116^{* * * *}$ & & & & & \\
\hline & 0,076 & & 0,036 & 0,033 & & & & & \\
\hline \multirow[t]{2}{*}{ LEXP } & 0,085 & & 0,044 & & $0,152 * *$ & & & & 0,119 **** \\
\hline & 0,128 & & 0,031 & & 0,060 & & & & 0,040 \\
\hline \multirow[t]{2}{*}{ LIMP } & $-0,031$ & & & & & $0,055^{* * *}$ & $0,074 * *$ & $0,091 * * *$ & \\
\hline & 0,055 & & & & & 0,023 & 0,035 & 0,025 & \\
\hline \multirow[t]{2}{*}{$\mathrm{LCO}_{2}$} & $-0,391 * * *$ & & $-0,294 * * *$ & $-0,275$ **** & $-0,239 * * *$ & $-0,325 * * *$ & $-0,329 * * *$ & $-0,251 * * *$ & $-0,176^{* * *}$ \\
\hline & 0,076 & & 0,063 & 0,058 & 0,073 & 0,054 & 0,050 & 0,064 & 0,060 \\
\hline \multirow[t]{2}{*}{ Sabit } & $-5,388$ & $-0,077$ & 3,736 & 2,140 & $-0,438$ & 6,263 & 8,761 & 8,935 & 10,771 \\
\hline & 15,875 & 1,777 & 7,482 & 6,101 & 1,230 & 6,885 & 6,253 & 7,519 & 8,616 \\
\hline NT & 667,000 & 667,000 & 667,000 & 667,000 & 667,000 & 667,000 & 667,000 & 667,000 & 667,000 \\
\hline WALDist & $67,05 * * *$ & 7,420 & $32,43^{* * * *}$ & $27,06^{* * * *}$ & $14,23 * * *$ & $60,70 * * *$ & $91,72 * * *$ & $40,59 * * *$ & $24,53^{* * * *}$ \\
\hline RMSE & 0,003 & 0,013 & 0,0104 & 0,011 & 0,0130 & 0,0105 & 0,010 & 0,011 & 0,012 \\
\hline
\end{tabular}

Tablo: 8

Modellerin CCEMG Uzun Dönem Katsayı Tahmin Sonuçları

Not: $\left.{ }^{*} \% 10\right),{ }^{* *}(\% 5),{ }^{* * *}(\% 1)$ düzeyinde anlamlllik seviyeleridir. RMSE (Root Mean Square Error) ortalama

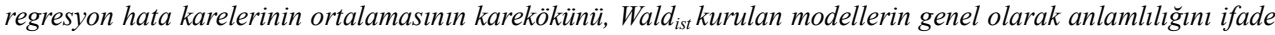
etmektedir. Tahminci katsayılarının altındaki değerler standart sapma değerleridir.

Tüm modeller için Tablo 8'de CCEMG, Tablo 9'da ise AMG tahmin sonuçları yer almaktadır. Modeller arasında karşılaştırma ve tercih kriteri olarak kullanılan RMSE değerinin 0 (sıfır)'a, $\mathrm{R}^{2}$ değerinin ise 1 (bir)'e yakın olması aynı bağımlı değişkene ait karşılaştırılan modeller arasındaki açıklama gücünün ve tercih edilmesinin daha uyumlu 
olacağını ifade etmektedir (Kaya vd., 2016: 6; Aydın, 2019: 217; Sun \& Xu, 2020: 7). Bu bölümde model karşılaştırmaları için RMSE uyumluluk ölçütü kullanılmaktadır. CCEMG ve AMG tahmin sonuçlarının genel olarak birbirine benzer sonuçlar verdiği gibi modeller arasında RMSE değerleri de benzer sonuçlar göstermektedir. Dolayısıyla hem CCEMG hem de AMG sonuçlarına göre 0 (sıfır)'a en yakın RMSE değerine sahip Model7 tercih edilecek ve yorumlanacaktır.

Tablo: 9

\section{Modellerin AMG Uzun Dönem Katsayı Tahmin Sonuçları}

\begin{tabular}{|c|c|c|c|c|c|c|c|c|c|}
\hline LEE & Model1 & Model2 & Model3 & Model4 & Model5 & Model6 & Model7 & Model8 & Model9 \\
\hline \multirow[t]{2}{*}{ LCOA } & 0,002 & $-0,008$ & $-0,020^{*}$ & & & & & & \\
\hline & 0,009 & 0,016 & 0,011 & & & & & & \\
\hline \multirow[t]{2}{*}{ LOIL } & $-0,004$ & 0,011 & & $-0,016^{*}$ & & & & & \\
\hline & 0,010 & 0,016 & & 0,010 & & & & & \\
\hline \multirow[t]{2}{*}{ LNAT } & $-0,009$ & $-0,001$ & & & $-0,001$ & & & & $-0,015 * * *$ \\
\hline & 0,008 & 0,013 & & & 0,009 & & & & 0,008 \\
\hline \multirow[t]{2}{*}{ LAGR } & 0,001 & $-0,117$ & & & $0,125 *$ & & & 0,182 & \\
\hline & 0,073 & 0,081 & & & 0,064 & & & 0,119 & \\
\hline \multirow[t]{2}{*}{ LSRV } & $0,272 * * *$ & 0,136 & & & & $0,546 * * *$ & & & \\
\hline & 0,098 & 0,123 & & & & 0,067 & & & \\
\hline \multirow[t]{2}{*}{ LIND } & $0,301 * *$ & 0,170 & & & & & $\mathbf{0 , 3 5 8 * * * *}$ & & \\
\hline & 0,147 & 0,105 & & & & & 0,110 & & \\
\hline \multirow[t]{2}{*}{ LPOP } & $-1,460$ **** & & $-0,724$ & $-0,574$ & & $-1,089 * *$ & $-0,891 *$ & $-1,221^{* *}$ & $-1,369^{* *}$ \\
\hline & 0,550 & & 0,611 & 0,617 & & 0,459 & 0,530 & 0,522 & 0,559 \\
\hline \multirow{2}{*}{ LOPN } & $-0,044$ & & & 0,006 & $-0,104 * * * *$ & & $-0,041 * *$ & & $-0,099 * *$ \\
\hline & 0,045 & & & 0,028 & 0,034 & & 0,019 & & 0,045 \\
\hline \multirow[t]{2}{*}{ LFDI } & 0,067 & & & & & 0,086 & & $0,204 * *$ & \\
\hline & 0,076 & & & & & 0,097 & & 0,101 & \\
\hline \multirow[t]{2}{*}{ LINV } & $-0,023$ & & $0,162 * * * *$ & $0,159 * * *$ & & & & & \\
\hline & 0,053 & & 0,028 & 0,032 & & & & & \\
\hline \multirow[t]{2}{*}{ LEXP } & $-0,045$ & & $0,058 * *$ & & $0,170^{* * * *}$ & & & & $0,166 * * * *$ \\
\hline & 0,055 & & 0,029 & & 0,056 & & & & 0,060 \\
\hline \multirow[t]{2}{*}{ LIMP } & 0,074 & & & & & $0,038 * *$ & 0,070 & 0,099 **** & \\
\hline & 0,053 & & & & & 0,018 & 0,043 & 0,028 & \\
\hline \multirow[t]{2}{*}{$\mathrm{LCO}_{2}$} & $-0,325 * * * *$ & & $-0,269 * * *$ & $-0,263 * * *$ & $-0,246^{* * * *}$ & $-0,361 * * *$ & $-0,365^{* * *} *$ & $-0,209 * * * *$ & $-0,142 * * *$ \\
\hline & 0,053 & & 0,063 & 0,060 & 0,070 & 0,052 & 0,061 & 0,066 & 0,066 \\
\hline \multirow[t]{2}{*}{ Sabit } & $11,854 * * * *$ & $4,287 * * *$ & $9,980 * *$ & $9,213^{*}$ & $3,957 * * *$ & $8,864 * *$ & $9,425 * *$ & $12,548 * * *$ & $15,110 * * *$ \\
\hline & 4,025 & 0,936 & 4,801 & 4,836 & 0,787 & 3,498 & 4,407 & 4,235 & 4,454 \\
\hline NT & 667,000 & 667,000 & 667,000 & 667,000 & 667,000 & 667,000 & 667,000 & 667,000 & 667,000 \\
\hline WALDist & $327,34 * * *$ & $18,16^{*}$ & $65,22^{*} * * *$ & $46,06^{* * * *}$ & $23,19 * * *$ & $123,59 * * *$ & $128,71^{*} * *$ & 42,47 *** & $48,29 * * *$ \\
\hline RMSE & 0,009 & 0,0160 & 0,0137 & 0,014 & 0,016 & 0,014 & 0,013 & 0,014 & 0,0150 \\
\hline
\end{tabular}

Not: *(\%10), **(\%5), ***(\%1) düzeyinde anlamllllk seviyeleridir. RMSE (Root Mean Square Error) ortalama regresyon hata karelerinin ortalamasinın karekökünü, Wald ${ }_{\text {ist }}$ kurulan modellerin genel olarak anlamliliğın ifade etmektedir. Tahminci katsayılarının altındaki değerler standart sapma değerleridir. CCEMG modelinde anlamsız olan sabit terim AMG modelinin her birinde anlamlı çıkmıştır.

Model7'ye göre, genel olarak bütün değişkenlerin hem işareti hem de büyüklüğü birbirine benzer sonuçlar vermiştir. Hem CCEMG hem de AMG sonuçları göz önüne alındığında sanayi geliri(üretimi) (LIND) ve ithalat (LIMP) enerji etkinliğini olumlu, nüfus (LPOP), açıklık (LOPN) ve karbondioksit emisyonu $\left(\mathrm{LCO}_{2}\right)$ ise olumsuz etkilemektedir. Katsayılar olarak incelendiğinde uzun dönemde enerji etkinliğini en fazla olumlu etkileyen sanayi gelir(üretim)indeki \%1'lik bir artış enerji etkinliğinde yaklaşık \%0.36 artışa, en fazla olumsuz etkileyen nüfusta meydana gelen \%1'lik bir artış ise enerji etkinliğinde yaklaşık $\% 0.89$ azalışı beraberinde getirmektedir. Ayrıca tüm modellerdeki anlamlı çıkan tüm değişkenlere dikkat edildiğinde Model7'deki gibi enerji etkinliğini en fazla olumlu etkileyen 
sanayi geliri(üretimi) ve hizmetler geliri iken en fazla olumsuz etkileyen ise nüfus olduğu görülmektedir.

Diğer taraftan, birçok değişkenin kullanıldığg ve çoklu doğrusal bağlantı sorunun görüldüğü Model1 (Bkz: EK 1, Tüm modellerin VİF Bilgileri, Model1) göz ardı edilirse; Model2-Model9 arası modeller ve teknikler (CCEMG ve AMG arası) geçişlerde; sürekli olarak LPOP'un ve $\mathrm{LCO}_{2}$ 'nin, fiyat olarak LCOA'nın işareti negatif bulunmuş olup; bu faktörlerdeki artışlar (azalışlar) enerji etkinliğini veya verimliliğini azaltıcı (artırıcı) bulunmuştur. Yine Model2-Model9 arası modeller arası geçişlerde; sürekli olarak LFDI'nin, LIMP'un, LEXP'nun, LINV'nin, LSRV'nın, LIND'nin işareti pozitif olarak tahmin edilmiş olup; bu faktörlerdeki artışlar enerji etkinliğini veya verimliliğini artırıcı bulunmuştur. LOPN'nun anlamsız bulunduğu model/AMG tahmincisi hariç, dışa açıklık oranı arttıkça Yükselen Ekonomiler enerji kullanım etkinliğini artırmaktadır. LAGR'nin, LOIL ve LNAT'un katsayılarının işaretleri model ve teknik geçişleri arasından tutarlılık göstermemiştir. Ancak fiyat değişkenlerinin anlamlı olarak tahmin edilen katsayıların aldığı işaretleri bu ülkeler için umulan teorik beklentiye uygun olarak tahmin edilmiş olup; bunlarda fiyat artışları enerji tüketimini azaltarak enerjinin etkin kullanımına yol açarken bu ülkelerde üretim azalışı etkisi ağır bastığından enerji verimi düşmektedir. Genelde üretim artışları ve dış ticaret (ihracat ve ithalat) artışları Yükselen Ekonomiler'de rekabeti tetiklediğinden ve bu rekabetin sürdürülebilir olabilmesinden dolayı enerjinin etkin kullanımını beraberinde getirmektedir. Yükselen Ekonomiler'de yatırımlar; yeni olduğundan dolayı teknoloji içeren sermaye yatırımları şeklinde olması da enerji verimliliğini artırıcı bulunmuştur. Elde edinilen bulgular, genel olarak teorik beklentileri karşılamış, ileri sürülen faktörlerin ve/veya hipotezlerin enerji üzerindeki etkisini kanıtlamıştır.

\section{Sonuç ve Değerlendirme}

Küreselleşme öncesi her ekonomi kendi içerisinde bulunan düzene göre şekillenirdi ve dış dünyayla ekonomik ilişkiler çok fazla yoktu. Küreselleşmeyle birlikte dünyada sermaye hareketliliğin serbest kalması ve ülkeler arasında oluşan ve giderek artan rekabet ve bunun sonucunda artan üretim ve buna bağlı olarak enerji kullanımı artmıştır. Üretimini artıran bir ekonomi iç pazara olan bağımlılı̆̆ını azaltmış, dış pazarlara girerek satışını, karını ve iç pazardaki rekabetini artırmış, fazla üretim kapasitesini satmıştır. Bunun sonucunda ise ihracat gelirleri artmış bu ise büyüme rakamlarına yansımıştır. En yüksek büyüme rakamlarına ise Yükselen Ekonomiler'de rastlanmıştır. Bu ekonomiler de ihracat ise genellikle ithal ettiği mallarla yapılmıştır. Ayrıca bazı ekonomilerde yaşanan ihracat hırsı enerji girdileri içerisinde yüksek paylara sahip olan fosil yakıt kullanımını artırmış ve bunun sonucunda çevre de bozulmalara neden olmuştur. Çevresel bozulmaların ise en büyük sebeplerinden biri insan kaynaklı faaliyetler sonucu çevreye salınan sera gazı emisyonlarından $\mathrm{CO}_{2}$ emisyonudur. Yani üretim artışı beraberinde ihracatı artırmış ve ülke ekonomisinde gelir artışına sebep olmuştur; ancak bu gelir artışının bir maliyeti olarak $\mathrm{CO}_{2}$ emisyonu artarak çevreye verilen zarar artmıştır. Bu yüzden enerji girdileri arasında fosil 
yakıt payının yüksek olduğu hem Yükselen Ekonomiler hem de dünya için enerjinin etkin kullanılmasının önemi artmıştır.

Bu çalışmada 23 Yükselen Ekonomi için 1990-2018 dönemi boyunca talep yanlı enerji etkinliğini etkileyen faktörler araştırılmıştır. Çalışmada değişkenlerin birim kök içerip içermediği test edilmeden önce birimler arası korelasyon sınaması yapılmış ve bunun neticesinde birinci nesil ve ikinci nesil birim kök testleri ile serilerin durağanlığ test edilmiştir. Bazı değişkenler arasında ortaya çıkan yüksek korelasyon katsayıları ve VIF değerlerinin yüksek çıkmasından dolayı çoklu doğrusallık problemini önlemek için modeller oluşturulmuştur. Sonra tüm oluşturulan modellerin enerji etkinliği üzerindeki etkisi araştırılmıştır. Eşbütünleşme testi kullanılarak modellerde bağımlı değişken ile açıklayıcı değişken arasında uzun dönemli bir ilişki olup olmadığına bakılmıştır. Tahminler tüm modeller de eşbütünleşme ilişkisinin bulunduğunu göstermektedir. Bu yüzden uzun dönemli ilişkiyi araştırmak için modellerde eğim parametrelerinin homojenliği ve yatay kesit bağımlılı̆̆ı test edilmiştir. Daha sonra tüm modellerde yatay kesit bağımlılığının bulunduğu ve heterojen eğime sahip olunduğundan CCEMG ve AMG uzun dönem katsayı tahmini yapılmıştır. CCEMG ve AMG sonuçları genel olarak birbirine benzer sonuçlar vermiş ve RMSE model tercih ve uyumluluk ölçütlerinden 0(sıfir)'a en yakın değerlere sahip olan Model7 tercih edilmiştir. Model7 sonuçlarına göre Yükselen Ekonomiler'de uzun dönemde en fazla enerji etkinliğini sanayi geliri artırırken en fazla olumsuz etkileyen ise nüfus bulunmuştur. Katsayılar incelendiğinde enerji etkinliğini en fazla olumlu etkileyen sanayi gelirindeki \%1'lik bir artış enerji etkinliğinde yaklaşık \%0.36'lık bir artış, en fazla olumsuz etkileyen nüfusta meydana gelen $\% 1$ 'lik bir artış enerji etkinliğinde yaklaşık \%0,89 azalış meydana getirmektedir. Ayrıca tüm modellerdeki anlamlı çıkan tüm değişkenlere dikkat edildiğinde Model7'deki gibi enerji etkinliğini en fazla olumlu etkileyen sanayi geliri ve hizmetler geliri iken en fazla olumsuz etkileyen ise nüfus olduğu görülmektedir.

İleri sürülen faktörlerin çoğu; tahmin edilen parametrelerin işaretleri modellerteknikler arası tutarlılık gösterdiği ve teorik beklentileri karşıladığı bulunmuştur. Endüstriyel ve hizmetler üretimi, ithalat, doğrudan yabancı sermaye yatırımı, sabit sermaye yatırımı, dış açıklık oranı, ihracat ve ithalat artışları enerji etkinliğini olumlu, nüfus ve karbondioksit emisyon salınımları, petrol ve kömür fiyat artışları enerji talebini azaltırken üretimi daha da kısmakta; fiyat artışı sonucu etkinlik artışı sağlanırken üretimin daha fazla kısılması sonucu üretimde kısma etkisi fiyat etkisinden büyük olduğundan bu ülkelerde enerji (petrol ve kömür) fiyat artışları enerji etkinliğini olumsuz etkilemektedir. Her bir değişkenin anlamlı bulunduğu bir model tahmin edilebilmiştir. Yükselen Ekonomiler'de rekabetçi üretim ve diş ticaret artışlarının enerji etkinliğini artırdığı bulunmuştur.

Sonuç olarak Endüstriyel ve hizmetler üretimi, ithalat, doğrudan yabancı sermaye yatırımı, sabit sermaye yatırımı, dış açıklık oranı, ihracat ve ithalat artışları, nüfus, karbondioksit emisyonu, petrol ve kömür fiyatlarında yaşanan değişmelerin Yükselen Ekonomiler'de enerji etkinliği üzerinde etkisinin olduğunu göstermektedir. Bu çalışmada elde edilen bulgular, dünya için Akal (2016) tarafından yapılan çalışmadaki GSYİH artışının, OECD ülkeleri için Chang vd. (2018) tarafından yapılan çalışmadaki sabit sermaye 
yatırımındaki artışın, Çin için Zhao ve Lin (2019) tarafından yapılan çalışmadaki dış ticaret artışının, Çin için Pan vd. (2019) tarafından yapılan çalışmadaki DYY artışının enerji etkinliğini olumlu etkilediği diğer taraftan Kuzey Amerika için Grossman ve Krueger (1991) tarafından yapılan çalışmadaki dış ticaret açıklık artışının, Gelişmekte olan ülkeler için Nepal ve Paija (2019) tarafından yapılan çalışmadaki nüfus artışının, G7 ülkeleri için Sadorsky (2009) tarafından yapılan çalışmadaki enerji fiyat artışlarının ve Çin için Tian vd. (2016) tarafından yapılan çalışmadaki $\mathrm{CO}_{2}$ emisyon artışının enerji etkinliğini olumsuz etkilediği sonuçlarıyla örtüşmektedir.

Çalışmada elde edilen sonuçlar 1şığında analize dâhil edilen Yükselen Ekonomiler'de politika yapıcılara önemli görevler düşmektedir. İlk olarak yükselen ekonomilerde karbondioksit emisyonlarının enerji etkinliğini önemli derecede olumsuz etkilemesi bu ekonomilerde fosil yakıt kullanımının yoğun olduğu ve çevre odaklı politikaların esnek bir şekilde uygulanmasıyla ilişkilendirilebilir. Bu yüzden çevre kalitesinin artışını olumlu etkileyebilecek alternatif enerjilerden yenilenebilir enerji kaynaklarına ilişkin teşvik ve yatırımlara önem verilmelidir. Ayrıca analize dâhil edilen birçok ülkenin yenilenemez enerji kaynakları açısından ithalatçı olduğu düşünüldüğünde, alternatif enerji kaynaklarının önemi bir kez daha ortaya çıkmaktadır. Diğer yandan, ekonomik ve sosyal potansiyelleri bakımından gelişmekte olan ülkelerden ayrışan Yükselen Ekonomiler, bir üst seviyeye çıkmak için hem ekonomik bir yük getiren yenilenemez enerji kullanımını azaltmalı hem de daha temiz enerji olan yenilenebilir enerji kaynaklarına yönelmelidir. Böylece hem ekonomik olarak özellikle cari açık açısından iyileşmeler oluşacak hem de kalkınma hedefleri doğrultusunda daha temiz ve yaşanabilir bir dünyanın meydana gelmesine yardımcı olunmuş olunacaktır. Bununla beraber çevre politikaları göz ardı edilmeden yabancı sermaye yatırımlarının ülkeye sürekli çekebilecek politikaların uygulanması da önem arz edecektir. Enerji etkinliğini olumlu yönde etkileyen sektörün, sanayi olduğunu gösteren güçlü bulguların elde edilmesi, Yükselen Ekonomiler'in sanayi sektöründe önemli dönüşümler gerçekleştirdiğini ortaya koymaktadır. Diğer yandan, enerji etkinliğinin sağlanmasında olumsuzluklara yol açan nüfus artışı, Yükselen Ekonomiler'de özellikle kentleşmenin yoğunlaşmasıyla konutlarda enerjinin etkinsiz kullanıldı̆̆ını ortaya koymaktadır. Dolayısıyla başta hanehalkları için çevre bilincinin artırılmasının yanında genel olarak eğitimde ve kitlesel iletişim alanlarında enerjinin nasıl etkin/verimli ve tasarruflu kullanılabileceği ile ilgili bilinçlendirme adımları atılarak, konutlar özelinde önemli yapısal dönüşümün sağlanması önemli görülmektedir. Böylece hanehalkları bilinçlenerek, enerjinin etkin/verimli kullanımının artırılması sağlanabilecektir.

Literatürde enerji yoğunluğunu (tersine enerji verimliliğini) etkileyen faktörlerin birçok çalışmada arz ve talep ayrımı yapmadan birkaç değişkenle araştırıldığı görülmektedir. Ancak bu çalışma enerji etkinliğini/verimliliğini talep yanlı etkileyebilecek birçok değişkenin yer aldığı bir çalışmadır. Bunu yaparken enerji etkinliğini etkileyen talep yanlı faktörler arasında enerji fiyatları, gelir, demografik ve diğer iktisadi birçok değişken kullanılmıştır. Yine çalışmada talep yanlı faktörlerle enerjinin etkin kullanımını belirleyen etmenler güncel dönem verileri ile araştırılmıştır. Ayrıca enerji etkinliği üzerine literatürel 
çalışmalar az olmakla birlikte bu Yükselen Ekonomilerin önemine binaen hiç çalışma bulunamamıştır.

Çalışmanın kısıtlarına bakıldığında ülkelerin enerji ithalatçısı veya ihracatçısı olduğuna bakılmaksızın 23 yükselen ekonomi için enerji etkinliği araştırılmıştır. Çalışmada kullanılan ülkelerden 16 ülke enerji ithalatçısı 7 ülke ise enerji ihracatçısı konumundadır. $\mathrm{Bu}$ ekonomiler için ayrı ayrı enerji etkinliğine bakılabilir. Ayrıca dünya enerji fiyatları yerine her ülkenin sahip olduğu enerji fiyatları kullanılabilir. Dolayısıyla her çalışmada olduğu gibi bu çalışmada da modellere koymayı arzu ettiğimiz değişkenler üzerine veri kisitları mevcuttur.

Bu çalışmayı izleyen araştırmalarda yükselen ekonomilerin de aralarında bulunduğu ülke grupları için enerji etkinliği daha geniş veri setinde çalışılabilir. Öyle ki ekonomik değişkenlerin yanında sosyal, politik ve kurumsal değişkenler kullanılarak daha geniş bir analiz yapılması daha geniş kapsamlı sonuçlar ortaya koyabileceği düşünülmektedir. Ayrıca bu ekonomiler için sektörel olarak enerji etkinliğinin incelenmesi de sektör kıyaslaması açısından önemli bulguları ortaya koyabileceği düşünülmektedir.

\section{Kaynaklar}

Abbas, S.K. \& H. Lan (2020), “Commodity Price Pass-Through and Inflation Regimes”, Energy Economics, 92(2020),1-11.

Adom, P.K. (2015), "Determinants of Energy Intensity in South Africa: Testing for Structural Effects in Parameters", Energy, 89(2015), 334-346.

Ağır, H. \& S. Özbek \& S. Türkmen (2020), “Türkiye'de Cari İşlemler Dengesinin Dinamikleri: VAR Analizi”, Maliye Araştırmaları Dergisi, 6(2), 57-66.

Akal, M. (2015), “A VARX Modelling of Energy Intensity Interactions Between China, the United States, Japan and EU”, Opec Energy Review, 39(1), 103-124.

Akal, M. (2016), "Modeling World Energy Use Efficiency, Price, and GDP”, Energy Sources, Part B: Economics, Planning and Policy, 11(10), 911-919.

Altıntaş, H. \& M. Mercan (2015), “Ar-Ge Harcamaları ve Ekonomik Büyüme İlişkisi: OECD Ülkeleri Üzerine Yatay Kesit Bağımlılı̆̆ı Altında Panel Eşbütünleşme Analizi”, Ankara Üniversitesi SBF Dergisi, 70(2), 345-376.

Antonietti, R. \& F. Fontini (2019), "Does Energy Price Affect Energy Efficiency? Cross-Country Panel Evidence", Energy Policy, 129(2019), 896-906.

Aslan, A. (2009), "Convergence Analysis of Per Capita Carbon Dioxide Emissions: 1950-2004”, Ege Akademik Bakış Dergisi, 9(4), 1427-1439.

Aydın, Y. (2019), “GAP Bölgesi Yarı Kurak İklim Koşullarında Class a Pan’dan Oluşan Günlük Buharlaşmanın Penman ve Priestley-Taylor (Pt) Modelleri ile Tahmini”, içinde: B. Kunter \& N. Keskin, Current Research and Assesments for Agricultural Science, 207220.

Beaumont, R. (2012), An Introduction to Statistics Correlation, <http://www.floppybunny.org/ Robin/Web/Virtualncrassroom/Stats/Basics/Part9.Pdf>, 06.02.2020. 
Bird, L. \& M. Bolinger \& T. Gagliano \& R. Wiser \& M. Brown \& B. Parsons (2005), "Policies and Market Factors Driving Wind Power Development in the United States", Energy Policy, 33(11), 1397-1407.

Boqiang, L. \& L. Hongxun (2015), "Do Energy and Environment Efficiency Benefit from Foreign Trade? The Case of China's Industrial Sectors", Economic Research Journal, 9(11), 127 141.

Bozkurt, E. \& A. Altıner (2018), "Finansal Erişimin Belirleyicileri”, Bingöl Üniversitesi Sosyal Bilimler Enstitüsü Dergisi, 8(16), 295-308.

Breusch, T.S. \& A.R. Pagan (1980), "The Lagrange Multiplier Test and its Applications to ModelSpecification in Econometrics", Review of Economic Studies, 47(1), 239-253.

Chang, C.P. \& C.C. Lee \& A.N. Berdiev (2015), "The Impact of Government Ideology on Energy Efficiency: Evidence from Panel Data", Energy Efficiency, 8(6), 1181-1199.

Chang, C.P. \& J. Wen \& M. Zheng \& M. Dong \& Y. Hao (2018), "Is Higher Government Efficiency Conducive to Improving Energy Use Efficiency? Evidence from OECD Countries", Economic Modelling, 72(2018), 65-77.

Chang, T.H. \& C.M. Huang \& M.C. Lee (2009), "Threshold Effect of the Economic Growth Rate on the Renewable Energy Development from a Change in Energy Price: Evidence From OECD Countries", Energy Policy, 37(12), 5796-5802.

Chen, Y.E. \& Q. Fu \& X. Zhao \& X. Yuan \& C.P. Chang (2019), “International Sanctions' Impact on Energy Efficiency in Target States", Economic Modelling, 82(2019), 21-34.

Choi, I. (1994), "Durbin-Hausman Tests for Cointegration”, Journal of Economic Dynamics and.Control, 18(2), 467-480.

Chong, C.H. \& W.X. Tan \& Z.J. Ting \& P. Liu \& L. Ma \& Z. Li \& W. Ni (2019), “The Driving Factors of Energy-Related $\mathrm{CO}_{2}$ Emission Growth in Malaysia: The LMDI Decomposition Method Based on Energy Allocation Analysis", Renewable And Sustainable Energy Reviews, 115(2019), 2-19.

Da Silva, P.P. \& P.A. Cerqueira \& W. Ogbe (2018), "Determinants of Renewable Energy Growth in Sub-Saharan Africa: Evidence From Panel ARDL”, Energy, 156(2018), 45-54.

Dawei, G. \& Z. Dequn \& W. Qunwei (2010), “International Trade, RANDD Technology Spillovers and Its Effect on Total-Factor Energy Efficiency in China", Management Review, <http://en.cnki.com.cn/Article_en/CJFDTotal-ZWGD201008018.htm>, 06.02.2020.

Eberhardt, M. \& F. Teal (2010), "Productivity Analysis in Global Manufacturing Production", University of Economics Department of Economics Discussion, <https://ora.ox.ac.uk/objects/uuid:ea831625-9014-40ec-abc5-516ecfbd2118>, 06.02.2020.

Eberhardt, M. \& S. Bond (2009), "Cross-Section Dependence in Nonstationary Panel Models: A Novel Estimator", Munich Personal Repec Archive, < https://mpra.ub.unimuenchen.de/17692>, 06.02.2020.

Fan, E.X. (2002), Technological Spillovers from Foreign Direct Investment-A Survey, Asian Development Bank, <http://hdl.handle.net/11540/2070>, 06.02.2020.

Gamtessa, S. \& A.B. Olani (2018), "Energy Price, Energy Efficiency, and Capital Productivity: Empirical Investigations and Policy Implications", Energy Economics, 72(2018), 650666. 
Göçer, İ. \& M. Mercan \& H. Hotunluoğlu (2012), "Seçilmiş OECD Ülkelerinde Cari İşlemler Açığının Sürdürülebilirliği: Yatay Kesit Bağımlılı̆̆ı Altında Çoklu Yapısal Kırılmalı Panel Veri Analizi”, Maliye Dergisi, (163), 449-467.

Grossman, G.M. \& A.B. Krueger (1991), "Environmental Impacts of A North American Free Trade Agreement, National Bureau of Economic Research", Cambridge, Working Paper, National Bureau of Economic Research.

Gu, W. \& X. Zhao \& X. Yan \& C. Wang \& Q. Li, (2019), "Energy Technological Progress, Energy Consumption, and $\mathrm{CO}_{2}$ Emissions: Empirical Evidence from China", Journal of Cleaner Production, 236(2019), 2-15.

Güney, T. (2017), "Population Growth and Sustainable Development in Developed-Developing Countries: An IV (2SLS) Approach”, Population, 22(4), 1255-1277.

Hang, L. \& M. Tu (2007), “The Impacts of Energy Prices on Energy Intensity: Evidence from China", Energy Policy, 35(5), 2978-2988.

Hatzigeorgiou, E. \& H. Polatidis \& D. Haralambopoulos (2011), " $\mathrm{CO}_{2}$ Emissions, GDP and Energy Intensity: A Multivariate Cointegration and Causality Analysis for Greece 1977-2007”, Applied Energy, 88(4), 1377-1385.

Hepaktan, C.E. \& S. Çınar (2011), “OECD Ülkeleri Vergi Sistemi Esnekliğinin Panel Eşbütünleşme Testleri ile Analizi”, Sosyal Bilimler Dergisi, 4(2), 133-153.

Hossain, M.S. (2011), "Panel Estimation for $\mathrm{CO}_{2}$ Emissions, Energy Consumption, Economic Growth, Trade Openness and Urbanization of Newly Industrialized Countries", Energy Policy, 39(11), 6991-6999.

Hull, D. \& B.P.Ó. Gallachóir \& N. Walker (2009), "Development of A Modelling Framework in Response to New European Energy-Efficiency Regulatory Obligations: The Irish Experience", Energy Policy, 37(12), 5363-5375.

Iddrisu, A.A. \& I.P. Alagidede (2020), "Revisiting Interest Rate and Lending Channels of Monetary Policy Transmission in the Light of Theoretical Prescriptions", Central Bank Review, 210.

Im, K.S. \& M.H. Pesaran \& Y. Shin (2003), "Testing for Unit Roots in Heterogeneous Panels”, Journal of Econometrics, 115(1), 53-74.

International Energy Agency (IEA) (2020), Data and Statistics, <www.iea.org>, 06.02.2020.

International Monetary Fund (IMF) (2015), World Economic Outlook, $<$ https://www.İmf.Org/External/Pubs/Ft/Weo/2015/02/Pdf/Text.Pdf>, 06.02.2020.

Kaya, S. \& S. Evren \& E. Daşcı (2016), "Yarı-Kurak İklim Koşullarında A Sınıfı Kap Buharlaşmasını Tahmini için Çeşitli Eşitliklerin Karşılaştırılması", Bursa Uludağ Ziraat Fakültesi Dergisi, 30(2), 1-9.

Kejun, J. (2009), "Energy Efficiency Improvement in China: A Significant Progress for the 11th Five Year Plan”, Energy Efficiency, 2(4), 401.

Lescaroux, F. (2008), "Decomposition of Us Manufacturing Energy Intensity and Elasticities of Components with Respect to Energy Prices”, Energy Economics, 30(3), 1068-1080.

Levin, A. \& C.F. Lin \& C.S.J. Chu (2002), "Unit Root Tests in Panel Data: Asymptotic and FiniteSample Properties", Journal of Econometrics, 108(1), 1-24.

Maddala, G.S. \& S. Wu (1999), "A Comparative Study of Unit Root Tests with Panel Data and A New Simple Test”, Oxford Bulletin of Economics and Statistics, 61(S1), 631- 652. 
Marques, A.C. \& J.A. Fuinhas \& J.P. Manso (2010), "Motivations Driving Renewable Energy in European Countries: A Panel Data Approach”, Energy Policy, 38(11), 6877-6885.

Menz, F.C. \& S. Vachon (2006), "The Effectiveness of Different Policy Regimes for Promoting Wind Power: Experiences from the States", Energy Policy, 34(14), 1786-1796.

Mingyong, L. \& P. Shuijun \& B. Qun (2006), "Technology Spillovers, Absorptive Capacity and Economic Growth", China Economic Review, 17(3), 300-320.

Mucuk, M. \& D. Uysal (2009), “Türkiye Ekonomisinde Enerji Tüketimi ve Ekonomik Büyüme”, Maliye Dergisi, 157(1), 105-115.

Nepal, R. \& N. Paija (2019), "Energy Security, Electricity, Population and Economic Growth: The Case of A Developing South Asian Resource-Rich Economy”, Energy Policy, 132, 771781.

Neves, S.A. \& A.C. Marques \& J.A. Fuinhas (2017), "Is Energy Consumption in the Transport Sector Hampering both Economic Growth and the Reduction of $\mathrm{CO}_{2}$ Emissions? A Disaggregated Energy Consumption Analysis", Transport Policy, 59(C), 64-70.

Özbek, S. \& S. Türkmen, (2020), "Finansallaşma, İşsizliği Artırıyor mu? E7 Ülkelerinden Yeni Kanıtlar”, Insan ve Toplum Bilimleri Araştırmaları Dergisi, 9(3), 2096-2115.

Özbek, S. (2020), "Fisher Etkisi: Yükselen Piyasa Ekonomileri Üzerine Bir Uygulama”, Uluslararası Ekonomi Siyaset İnsan ve Toplum Bilimleri Dergisi, 3(4), 240-251.

Pan, X. \& S. Guo \& C. Han \& M. Wang \& J. Song \& X. Liao (2019), "Influence of FDI Quality on Energy Efficiency in China Based on Seemingly Unrelated Regression Method", Energy, 192(2019), 1-7.

Pesaran, H. \& R. Smith \& K.S. Im (1996), Dynamic Linear Models for Heterogenous Panels, in the Econometrics of Panel Data, Springer, Dordrecht, 145-195.

Pesaran, H. (2004), “General Diagnostic Tests for Cross Section Dependence in Panels”, University of Cambridge, Cambridge Working Papers in Economics, 435, 138.

Pesaran, M.H. \& A. Ullah \& T. Yamagata (2008), “A Bias-Adjusted LM Test of Error CrossSection Independence”, The Econometrics Journal, 11(1), 105-127.

Pesaran, M.H. \& T. Yamagata (2008), “Testing Slope Homogeneity in Large Panels”, Journal of Econometrics, 142(1), 50-93.

Pesaran, M.H. (2007), “A Simple Panel Unit Root Test in the Presence of Cross-Section Dependence", Journal of Applied Econometrics, 22(2), 265-312.

Raza, M.Y. \& M.T.S. Shah (2019), “Analysis of Coal-Related Energy Consumption in Pakistan: An Alternative Energy Resource to Fuel Economic Development, Environment", Development and Sustainability, 22(2020), 6149-6170.

Sadorsky, P. (2009), "Renewable Energy Consumption, $\mathrm{CO}_{2}$ Emissions and Oil Prices in the G7 Countries", Energy Economics, 31(3), 456-462.

Sahabi, A.M. (2019), "Finansal Performans Ölçütlerinin Firma Değeri Üzerindeki Etkisi: Borsa İstanbul'da Bir Araştırma”, Yayımlanmış Doktora Tezi, Anadolu Üniversitesi/ Sosyal Bilimler Enstitüsü, Eskişehir.

Sargan, J.D. \& A. Bhargava (1983), "Testing Residuals from Least Squares Regression for Being Generated by the Gaussian Random Walk", Econometrica: Journal of the Econometric Society, 51(1), 153-174. 
Stock, J.H. (1999), “A Class of Tests for Integration and Cointegration. Cointegration, Causality and Forecasting", içinde: A Festschrift in Honour of Clive WJ Granger, 137-167.

Sun, W. \& C. Xu (2020), "Carbon Price Prediction Based on Modified Wavelet Least Square Support Vector Machine", Science of the Total Environment, 754(2020), 1-10.

Syzdykova, A.O. (2019), "The Effect of Foreign Direct Investment on Economic Growth: The Case of Central Asian Countries", International Journal of Cultural and Social Studies, 5(1), 291-307.

Tian, J. \& D. Yang \& H. Zhang \& L. Liu (2016), "Classification Method of Energy Efficiency and CO2 Emission Intensity of Commercial Trucks in China's Road Transport”, Procedia Engineering, 137(2016), 75-84.

Ulusoy, V. (2006, Mayıs), "Ekonomik Büyüme ve Enerji Tüketimi: Bir Ekonometrik Uygulama”, $I$. Ulusal Türkiye'de Enerji ve Kalkınma Sempozyumu, İstanbul.

Uygur, E. (2012), “Doğrudan Yabancı Yatırımı Beklerken”, Econstar, <http://hdl.handle.net/10419/81648>, 06.02.2020.

Valadkhani, A. \& R. Smyth \& J. Nguyen (2019), "Effects of Primary Energy Consumption on $\mathrm{CO}_{2}$ Emissions Under Optimal Thresholds: Evidence From Sixty Countries over the Last Half Century", Energy Economics, 80(2019), 680-690.

Van Ruijven, B. \& D.P. Van Vuuren (2009), "Oil and Natural Gas Prices and Greenhouse Gas Emission Mitigation”, Energy Policy, 37(11), 4797-4808.

Vieira, N.D.B. \& L.A.H. Nogueira \& J. Haddad (2018), “An Assessment of $\mathrm{CO}_{2}$ Emissions Avoided by Energy-Efficiency Programs: A General Methodology and A Case Study in Brazil", Energy, 142(2018), 702-715.

Wang, S. (2017), "Impact of FDI on Energy Efficiency: An Analysis of the Regional Discrepancies in China”, Natural Hazards, 85(2), 1209-1222.

Westerlund, J. (2008), "Panel Cointegration Tests of the Fisher Effect", Journal of Applied Econometrics, 23(2), 193-233.

Zeren, F. \& H.T. Akkuş (2020), “The Relationship Between Renewable Energy Consumption and Trade Openness: New Evidence from Emerging Economies", Renewable Energy, 147(2020), 322-329.

Zhang, X.P. \& X.M. “Cheng \& J.H. Yuan \& X.J. Gao (2011), Total-Factor Energy Efficiency in Developing Countries", Energy Policy, 39(2), 644-650.

Zhao, H. \& B. Lin (2019), "Will Agglomeration Improve the Energy Efficiency in China's Textile Industry: Evidence and Policy Implications”, Applied Energy, 237(2019), 326-337. 
Naimoğlu, M. \& M. Akal (2021), "Yükselen Ekonomilerde Enerji Etkinliğini Talep Yanlı Etkileyen Faktörler", Sosyoekonomi, 29(49), 455-481. 